\title{
Doubts about the validity of the species name Hipparchia hermione (LinNAEus, 1764), it being associated with the two species Hipparchia alcyone ([DENIS \& SCHIFFERMüLLER], 1775) and Hipparchia genava (FRUHSTORFER, 1908) following the designation of a lectotype by KUDRNA (1977) (Lepidoptera: Nymphalidae, Satyrinae)
}

\author{
- First part -
}

\author{
David JUTZELER
}

\begin{abstract}
Preface: In 1977, Otakar KudRna (*1939- +2021 , obituary see BALlEtTo and LeIGHEB, 2021) published his "Revision of the Genus Hipparchia", where he classified all the known species and forms of this genus according to characters of wings, androconia, male genital armatures and further subjective criteria. Until today, KuDRNA's study is considered as the guideline of systematics of the genus Hipparchia. He selected there a lectotype specimen of a Rock Grayling male in the Linnaean collection. "Hipparchia hermione LinNaEus, 1764" is therefore, at the moment, the technically correct name to identify the species. The "International Commission of Zoological Nomenclature" (ICZN) has nothing to add at this point; it only comments on cases submitted to it in the Bulletin of Zoological Nomenclature. Within the meaning of the present study and in accordance with VERITY (1913), this damaged specimen without abdomen represents the same species as Ignaz SCHIFFERMÜLLER - allegedly the only author of the Vienna directory (see KuDRNA and B., 2005, p. 5) - has described under H. alcyone from the Vienna region by referring to a coloured copper engraving published by RöSEL VON ROSENHOF (1755).

KUDRNA's "Revision" became the starting point of an extended scientific research activity during my free time containing, as a matter of priority, the examination of problem cases of systematics by checking the preimaginal characters of many rearing series from different sites. It turned out that a number of classifications proposed by KUDRNA (1977) had to be reassessed as soon as characters of the pre-imaginal stages were available. The most complex case I have verified concerned the third European Grayling species which Leraut (1990) introduced under the name of Hipparchia genava (Frunstorfer, 1908). KudRna (1977) failed to separate this species from H. alcyone (D. \& S., 1775). Throughout his life, he never agreed with LERAUT's opinion. In recent years, KuDRNA had hoped that genetic examinations would make redundant every rearing attempt by amateur lepidopterists and furnish the proof that his opinion was the correct one. Since he never undertook any rearing experiments, his systematics were based only on prepared imagines being housed in museum collections. He saw himself as a person with the competency to decide within a few minutes upon complex questions of taxonomy and ignored completely the assessments of others.

For verifying the effective rank of $H$. genava, I had to examine also the two most closely related species: Hipparchia fagi and $H$. alcyone by rearing them all ex ovo with material from several widely spaced sites. Already on finalising my rearing work of this group, it became apparent that LERAUT (1990) had been on the absolutely right path by accepting a third Grayling species, within this group. For the first time, I published the results of my rearing attempts between 2002 and 2006 in several articles in the quarterly bulletin Linneana Belgica and I readily provided information on this case to interested colleagues. Over time only, I realized that the Rock Grayling I knew from the volume on butterflies (Diurna) by Forster and WoHLFAHrT (1955) as from the guides by HigGiNs and RiLEY (1970-84) under the name of $H$. alcyone had become H. hermione, because of the lectotype designation by KuDRNA (1977). A stony path was in front of me to substantiate the factual correctness of the view taken by LeRAUT (1990). Complex clarifications by Peter RUSSELL furnished well-founded arguments on the complex scientific issue why the use of the name "hermione LiNNAEUs, 1764" should be rejected for the Rock Grayling previously known as H. alcyone.
\end{abstract}

\section{History of the Grayling problem}

\section{Problems with identification the "Valais Rock} Grayling": As one of the promotors of the Swiss standard work "Tagfalter und ihre Lebensräume" (Lepidopterologen-Arbeitsgruppe, 1987), I was involved as a photographer of 750 colour photographs being published there, but also as a scientific editor and revisor of species descriptions. Already before this commitment, I had recognized that the Grayling present in the central Valais pine forest zone above Ausserberg could not be identified with the help of the figures being available at that time in the guides by FORSTER and WOHLFAHRT (1955) and HigGins and RILEY (German edition of 1978). Its wingspan did not match with that of the "Tree Grayling" ( $H$. fagi) or with that of the Rock Grayling (named H. aelia and
H. alcyone in these works) figured in these guides nor was the design on the hindwing-underside in accordance with that of either of these two species. The authors of "Tagfalter und ihre Lebensräume" (L.A., 1987) were not aware of these differences in wing morphology. Finally, the Valais Grayling was treated there as Rock Grayling under the name of Hipparchia alcyone (D. \& S., 1775) and juxtaposed to the Tree Grayling (H. fagi), species known in Switzerland mainly from the Jurassic chain and the Tessin.

LERAUT (1990) enables the identification of the "Valais Rock Grayling": The forementioned problem of identification began to be solved when the article "Contribution à l'étude des Satyrinae de France" by Patrice Leraut (1990) in the bulletin Entomologica Gallica was published. On individuals of the alleged Rock Grayling from the French Alps 
and from the Pyrenees, LERAUT established different numbers of rods on their Jullien's organ. He concluded the existence of two species and designated one of them as Hipparchia alcyone (D. \& S.) and the other, following the study by FrUHSTORFER $(1908,1910)$, as Hipparchia genava FRUHST. It was clear to me that the Grayling observed by myself above Ausserberg was Hipparchia genava. The idea was born to check the characters of pre-imaginal stages of the two presumed species by rearing them and to search for stable characteristics in order to get a confirmation of the species diversity but also for obtaining reared imagines with uncontested identity to enable the determination of species-specific characters for distinguishing more easily between the imagines of the two species.

Rearing Grayling series on the balcony: the above-mentioned study by LERAUT furnished the initial idea of all my rearing experiments carried out with several taxa of the Grayling group (alcyone, genava, fagi and syriaca). The examined series came from a total of 9 countries. Many of the required series of ova were contributed by colleagues and specialists who had received by post a cage with my instructions. The evaluation of the rearing series followed in the period from 2001-2006 in Linneana Belgica and was distributed over several articles. Approximately 100 imagines of $H$. alcyone and 100 of $H$. genava resulted from the rearing series, of which examination was a great interest to me. All the emerged individuals furnished useful distinctive features regarding the shape and design of wings. A particular difficulty to determine the characters of wing design of diagnostic valour concerned the high individual variation of all the individuals of the whole Grayling group.

Swiss institutions and "Lepiforum" adopt the model proposed by LERAUT (1990): After editing my studies in Linneana Belgica, some Swiss colleagues asked my opinion to the question whether the Rock Grayling represents in fact two species as it was claimed by LERAUT (1990). I confirmed this finding. Both, the "Centre suisse de cartographie de la faune" (CSCF) and the Biodiversity Monitoring Switzerland (BDM) accepted afterwards the species of the Grayling group in accordance with LeRAUT. Since then, the "Swiss Rock Grayling" with local populations in the Valais and the Jurassic chain is recorded always as Hipparchia genava by all the biologists working for these institutions. Every Swiss lepidopterist knows meanwhile that the Rock Grayling occurring in Germany and in the surroundings of Vienna: Hipparchia alcyone D. \& S., is not indigenous to Switzerland. By the way, LeRAuT's model has been applied also by the well-known German Internet platform "Lepiforum" but not so by the Finnish platform "funet. $f$ " where the Valais Grayling is called $H$. hermione genava.

LERAUT's model in the book "La Vie des Papillons" (LAFRANCHIS et al. 2015): In 2010, the French lepidopterist Tristan LafRanchis who accompanied scientifically and linguistically many of my approx. 50 contributions in the Belgian journal Linneana Belgica asked for my assistance with his book project "La Vie des Papillons", comprising some 750 pages. This cooperation turned out to be a unique opportunity to include my research findings from the examination of a multitude of documented rearing experiments of many species including those of individuals from the genera Melitaea and Erebia and opened the opportunity to present the species Hipparchia genava introduced by LERAUT to a wider audience. Coincidentally Tristan LAFRANCHIS examined the situation of distribution of alcyone and genava in southern France and presented the results on distribution maps, both on his website and in his book.
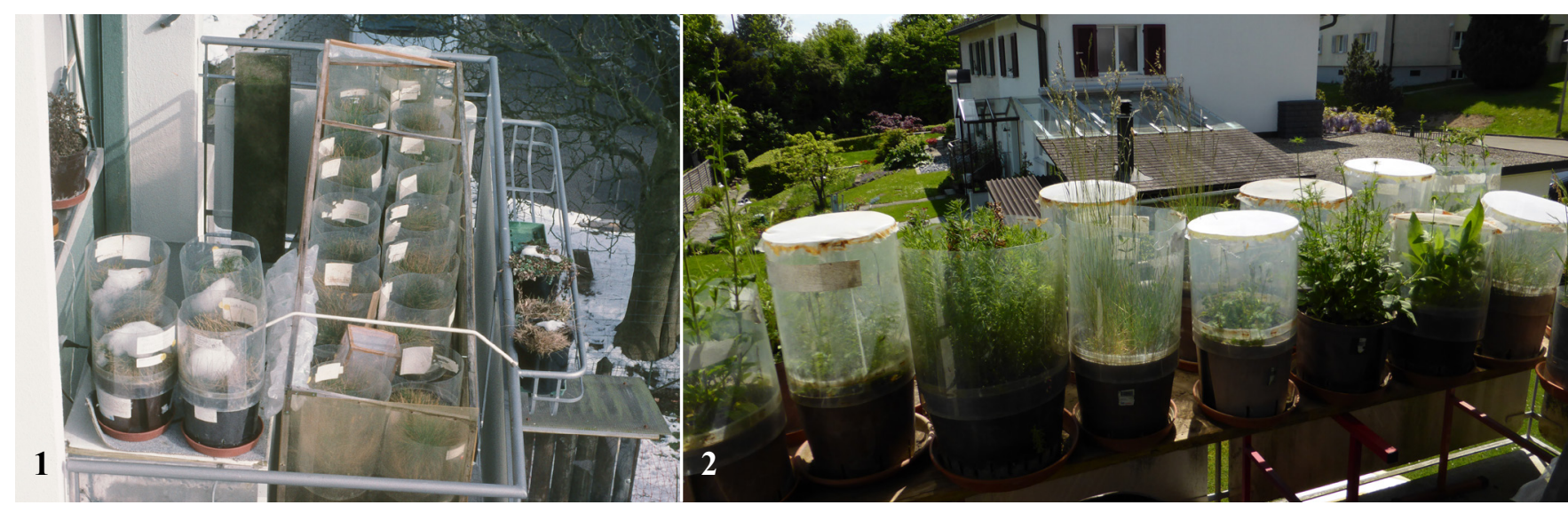

Figs. 1-2. Research station on D. JUTZELER's balcony in February 2003 when the rearing programme with the species of the Grayling group still was ongoing. 1. Altogether 18 pots with diameter of $22 \mathrm{~cm}$ could be placed inside the heatable greenhouse construction lying on a clapboard. 2. Pots on 10.05 .2015 being planted with different host-plants for rearing simultaneously several butterfly species for the book "La Vie des Papillons" (LAFranchis et al. 2015): Boloria selene, Brenthis ino, Erebia meolans, Melitaea didyma, Minois dryas, Satyrus ferula, Boloria titania and Erebia aethiops. If caterpillars tended to escape or if the emergence of imagines was expected, the transparent cylinder made from Petglass (traded as Guttagliss) could be closed with a transparent netting for curtains with $1 \mathrm{~mm}$ mashes. The pot in the middle without a netting is planted with Festuca ovina for rearing Satyrinae such as the three Graylings. Photographs David JutzeLER 
Overall presentation in Entomologica romanica: Already in the time before the book project with T. LAFRANCHIS, I wanted to provide an overall display of the Grayling problem. When I visited the comprehensive butterfly collection of the "Zoölogisch Museum Amsterdam" (nowadays housed in Leiden) during the years after the millennium, I reviewed and rearranged there all the drawers containing Grayling specimens and I separated the abdomens of about 60 individuals bringing them to my friend Guido VolPE in Castel Volturno (Campania) who prepared and photographed the genitalia. For a long time, this result remained without evaluation. Prof. László Rákosy from the Babeș-Bolyai University (Cluj, Romania) enabled me to publish the results in the peer-reviewed bulletin Entomologica romanica. Following his instructions, the amended article was provided to the author as a pdf prior to publication. I examined the Grayling specimens in the following Museums: Bad Dürkheim (Pfalzmuseum), Frankfurt (Senckenberg), Karlsruhe (SMNK), Strasbourg (MHNS), Genoa (Museo Giacomo Doria), Münchenstein (collection of the Entomological Society of Basel) and British Museum of Natural History (BMNH) in London. The distribution resulting from the sites indicated on the labels of all the examined preparations in the collections of the museums visited, comprising also that of FRUHSTORFER's type material of genava in the collection of the BMNH, matched perfectly with the distribution of the species alcyone and genava resulting from my extended rearing program carried out from 1999-2006 on my balcony. In spring 2017, the pdf file of the precursor version of this study in Entomologica romanica was ready for transmission to interested colleagues, specialists and institutes. On the occasion of a lively, subsequent exchange of opinions on the Internet between interested entomologists and Gerardo LAMAS of the ICZN-Commission, my article achieved much recognition and approval by a majority of participants.

Violent rejection by KUDRNA: About three months after transmission the link of the precursor study, KUDRNA surprisingly complained that he couldn't find this link and asked me for a copy. Shocked by the fact that a peer-reviewed journal was about to allow the publication of my manuscript, he made first serious threats against myself and, afterwards, against the editor responsible, causing the manuscript to be rejected for publication. In the manuscript, I illustrated KUDRNA's errors by reproducing some of his figures illustrating "Hipparchia hermione Linnaeus, 1764" in his "Revision". I established that the genital armature fig. 87 (Digne) and the Jullien organ fig. 86 (Aspromonte) shown there belonged to $H$. genava. However, there was no specimen figured in his "Revision" representing $H$. genava. KudRNA interpreted my action as a copyright infringement thus intending to prosecute the responsible editor in Cluj. He argued that a university publication is obliged to apply the species names with official validity. In a first response, L. Rákosy expected me to rename Hipparchia alcyone and $H$. genava to Hipparchia hermione hermione and Hipparchia hermione genava in order to satisfy KUDRNA's view. By applying these names, I would have denied however the specificity of $H$. genava and $H$. alcyone under acceptance of an increasing chaos with KUDRNA's hermione.

Higgins and RiLey (1978) refused Kudrna's "hermione LINNAEUS, 1764": There is no doubt that LERAUT (1990) knew of KUDRNA's "Revision" but his refusal to use the name hermione instead of alcyone may be related to HigGins and RiLEY, publishers from 1970 to 1984 of the popular field guides, with issues in several languages. In an article published in 1978 in "Entomologist's Gazette", the two authors argued against the reuse of the name hermione to replace now the recognized and frequently used name $H$. alcyone. Their wording: "On page 27 of his "Revision", KUDRNA (1977) purports to designate as lectotype of "hermione LINNAEUS, 1764" a specimen in the Linnaean collection in London. This designation is surely invalid as there is no evidence to suggest that the specimen in question was ever in the collection of Queen Ulrica, as it must have been, in order to satisfy the condition of Article 74 of the International Code of Zoological Nomenclature that governs the selection of lectotypes. The action should be ignored». There is no doubt that KUDRNA affronted the two London specialists naming the species in their guides $H$. alcyone since 1970, the correct and valid species name at that time according to Hemming (1960). Even in all their subsequent editions of their guide, HigGINs and RILEY continued to use this name, considering the renaming as unfounded. By the way, the name of alcyone was used also in the guides by TOLMAN and LEWINGTON (1997 and 2008).

Even the British lepidopterist Peter Russell considers the original specimen used by LINNAEUS to describe "Papilio hermione" as unknown: up to now, all the efforts by specialists to find the butterfly specimen which LinNaEus kept in sight when he described the taxon hermione were unsuccessful. This description was based on a specimen in the collection of Queen Ulrika of Sweden, but such a specimen does not exist in this collection today, a fact noted by Aurivillius (1882). Unfortunately, C.A. CLERCK $(1759,1764)$ who painted, under LiNNÉ's eyes some butterflies in Queen Ulrika's collection for posterity did not paint any original specimen of Pap. hermione. As a point of note - there exist two published volumes of paintings and, besides these, an unbound and unpublished collection of CLERK's paintings are housed in the collections of the "Royal Swedish Academy of Sciences" in Stockholm. After the death of Queen Ulrika in 1741, the state of her collection deteriorated dramatically until it was bequeathed by King Gustav to the Uppsala University in 1803. On its arrival in 1804, it was catalogued by Carl Peter ThunberG (1743-1828) who was considered to be one of LINNÉ's 'Apostles' (highly thought of students) because he 


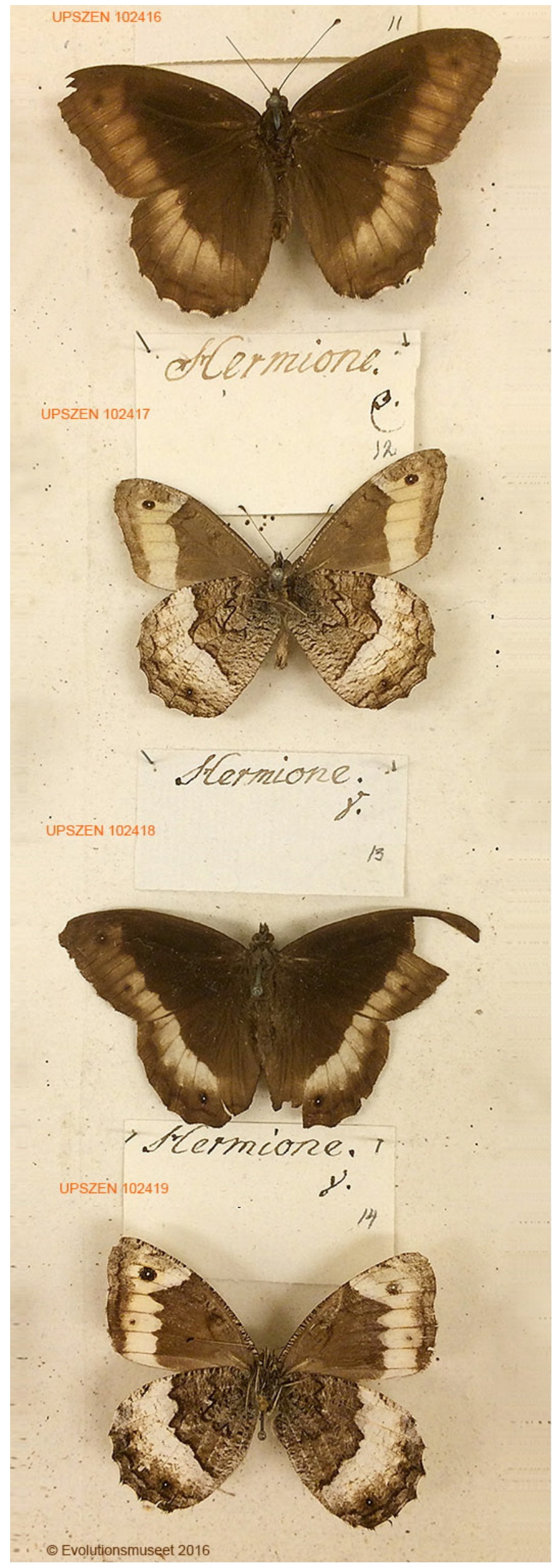

Fig. 3. The series of Papilio hermione in C.P. THUNBERG's collection at the Uppsala University Museum of Evolution, Zoology section (UUZM), Sweden. All identifiable as Hipparchia fagi ScOPOLI, 1763. Photograph John TenNENT, 4.06.2016. worked directly under LINNAEUs until his death in 1778. Thus, THUNBERG would have been familiar with LINNÉ's hermione and he did not register any individual of hermione in Queen Ulrika's collection in 1804. Even possible specimens labelled hermione in the personal collection of LINNÉ in Uppsala wouldn't have escaped THUNBERG's attention before LiNNÉ's widow and daughter sold it to J.E. SMITH in London in 1784. THUNBERG's personal collection is still housed in Uppsala and contains 4 individuals captioned "Hermione" whose appearance corresponds with the very small race of fagi occurring once in the Schwanheim forest near Frankfurt a. M. (named "Eumenis fagi ssp. sigurdrifa" by FrUHSTORFER, 1908) which was often confused with the Rock Grayling = H. alcyone ([DENIS \& SCHIFFERMÜLLER], 1775). More details see submission in preparation by Peter RUSSELL with Richard VANE-WRIGHT to the commission to conserve nomenclatural stability.

The chaos around LINNE's Papilio hermione was for the first time put in order by SCHIFFERMüLLER (D. \& S., 1775): In his listings of species of 1764 (Museum Ulricae) and 1767 (Systema naturae), LinNÉ characterized his Papilio hermione in such a broad way that his description is applicable to several species. If one takes as a measure LINNÉ's quotations referring to the figures of contemporary authors, then he mixed 4 species under the same umbrella - a not uncommon phenomenon occurring in the Linnaean descriptions. The fact that the name of hermione was used during more than 200 years primarily to designate the Tree Grayling is based on LINNÉ's quotations in "Systema naturae" from 1767, the first name mentioned there referring to Scopoli's "Entomologia carniolica" from 1763 with a clearly recognizable figure of the actual species fagi from Carniola, consisting mainly of Slovenia, and the last-mentioned name on the figure of the actual species alcyone from Germany in the $3^{\text {rd }}$ part of the "Monthly published insect amusements" by RÖSEL VON ROSENHOF (1755). For the systematics of Graylings of the following 200 years however, SCHIFFERMÜLLER's decision was particularly significant to refer the name of hermione only to the larger sized species in Carniola. As LINNÉ (1764) had linked Pap. hermione with the actual species circe in 1764, SCHIFFERMÜLLER added the older synonym of "P. Fagi Scop." to his Pap. hermione to define it more precisely (see fig. 8). Furthermore, SCHIFFERMüLLER introduced the name of alcyone to design the Rock Grayling still occurring around Vienna, because RöSEL's presentation of the German Rock Grayling took place at the time before the binominal nomenclature was brought into being. The reason why SCHIFFERMÜLLER gave preference to the younger name "hermione LINNÉ, 1764 and 1767" over the older name "fagi ScOPOLI, 1763" could be interpreted as a sign of respect towards LINNÉ. Only FRUHSTORFER $(1908,1910)$ considered the older publication date of Scopoli's fagi as more significant than the cult around LINNÉ's personality. By naming the Tree Grayling as 


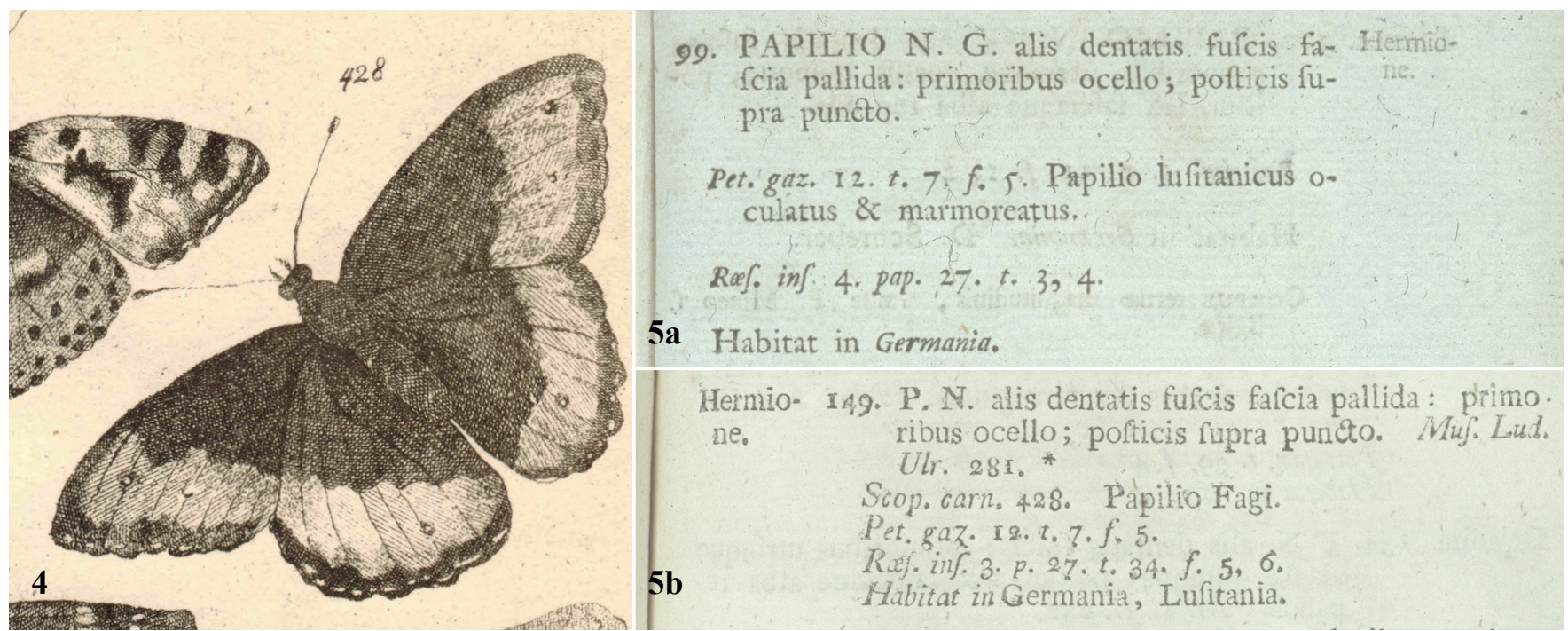

Fig. 4. Scopoli's figure of Pap. fagi from Carniola in 1763. Fig. 5. LinNAEus' descriptions of P. hermione in 1764 (5a) and $1767(5 b)$.
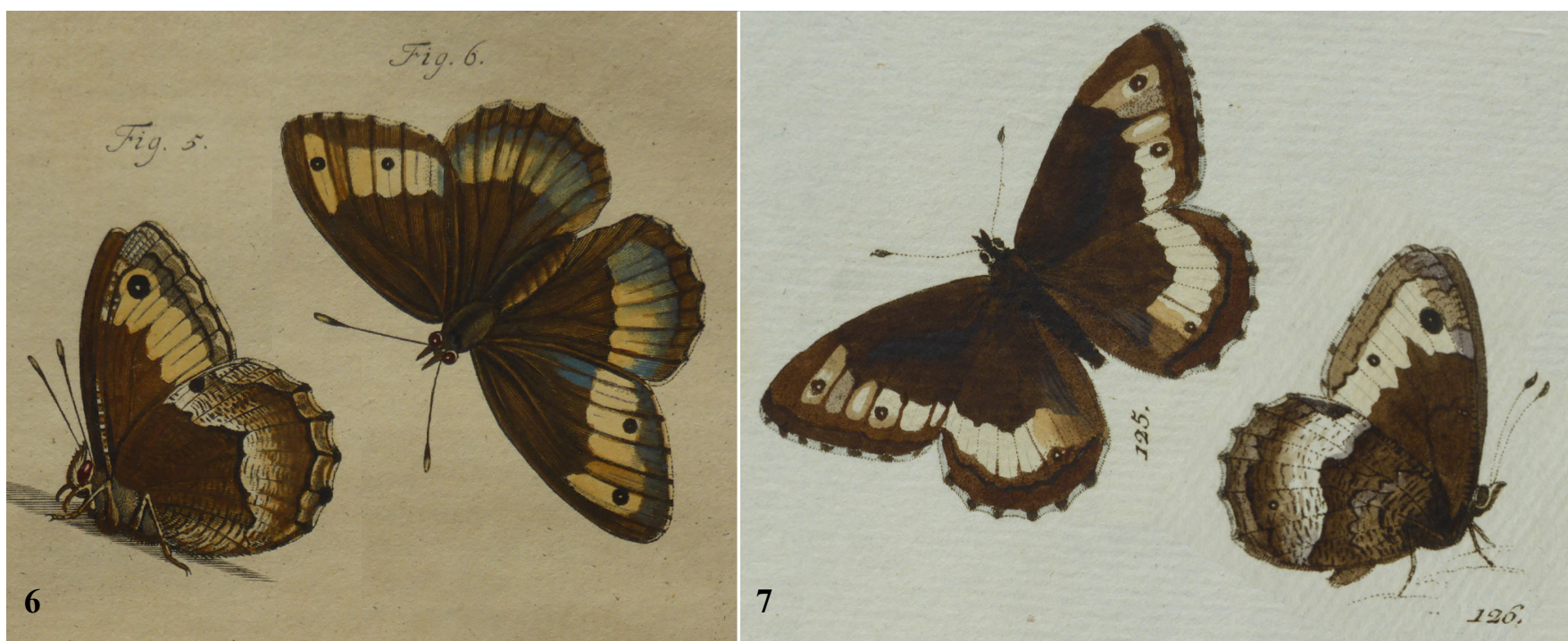

Fig. 6. The two figures 5 and 6 of RöSEL VON RosENHOF's “Dark brown, yellow ocher forest butterfly with two black ocelli on the forewings" dating 1755 represent the species subsequently known as Hipparchia alcyone (D. \& S., 1775). LINNÉ (1767) as well as SCHIFFERMÜLLER (D. \& S., 1775) referred to this coloured copper engraving of remarkable quality. Fig. 7. HüBNER's two figures 125 and 126 of Papilio Alcyone on plate 27 dating from 1800. HüBNER indicated "Austria" as the home (TL) of Pap. Alcyone. Therefore, it is obvious to believe that HüBNER's original specimens were caught in the surroundings of Vienna, the only Austrian region being inhabited with alcyone. These historic engravings show some very typical characters of alcyone: The apex of forewings is of pointed shape, the forewing band is often deeply indented and mostly ornated with two ocelli, the interior contour of the hindwing is of omega shape (see HüBNER's fig 126) and sometimes angulated in the middle section (see RösEL's fig. 5).

"Eumenis fagi Scopoli, 1763", he asserted gradually the priority of the name fagi, thus placing the name of hermione as a junior synonym of fagi, a feature completely ignored by KUDRNA in his "Revision".

Extreme variability and the fact that 5 of 6 countries are populated by only one of the two smaller species prevent $H$. genava to be recognized as a third Grayling species: SCHIFFERMÜLLER's view (D. \& S., 1775) should have determined widely in Europe the still prevailing idea of a large and of a small sized Grayling species. The generally huge range of variation of the wing pattern but also of the genital armatures of all the three Grayling species could have tipped the scales that the third species $H$. genava escaped during decennials the attention of specialists being unable to find watertight distinctive marks characterizing this third Grayling species (wherein I was fortunately successful with my extensive rearing program). Instead, one managed by attributing $H$. genava once to the larger sized species hermione (within the meaning of fagi) and, another time, to the smaller alcyone depending on one's subjective perception. The fact that the subsequently quoted countries are inhabited by two Grayling species with always one of the two smaller species only, could also have consolidated the idea in these countries that they are populated by only a large Grayling species and a Grayling species of smaller size. This 


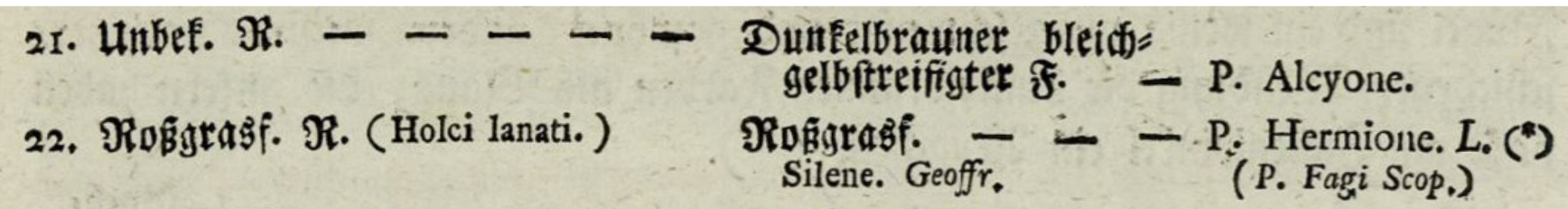

Fig. 8. Pap. Alcyone and Pap. Hermione L. in the Vienna directory (D. \& S., 1775), the second name being completed with the synonym "P. Fagi Scop."

is the situation prevailing in Italy and Switzerland being inhabited with only fagi and genava but also in Germany, Austria and Spain where only fagi and alcyone occur. As it was correctly recognized first by LERAUT (1990), France is the only European country where we find significant populations of all the three species: fagi, genava and alcyone. What about Italy, one single record of alcyone from 1973 is known to me. I detected the 4 proofs labelled Celle Ligure (Savona, Liguria) in the Broszkus collection housed in the "Pfalzmuseum für Naturkunde Bad Dürkheim" (Germany) (see 2 $2^{\text {nd }}$ part). Confirmation of this discovery in the field is still outstanding.

KUDRNA's difficulties with FruHSTORFER's type material of $\boldsymbol{H}$. genava in London: KUDRNA would have preferred to preparate himself the two genital armatures of the two males of the syntype series of genava in the FRUHSTORFER collection at the BMNH, but the museum prevented him from doing this. Because of missing genital preparations at the time of printing his "Revision", KUDRNA finally decided in a subjective way to attribute genava to his hermione. Only later, the preparation of the male genital armatures of the forementioned type series of genava was carried out by Phil ACKERY, at that time being conservator of the lepidoptera collection at the BMNH. From KudRNA's (2001) treatise "On the identity, status and type material of Eumenis fagi genava Fruhstorfer, 1907" (recte: 1908), it arises that he identified one of the two genital preparations as belonging to $H$. fagi fagi (Tree Grayling) and the other to his $H$. hermione hermione (Rock Grayling). In KuDRNA's "Distribution atlas" of 2015, we read that one of the genital armatures he had determined in 2001 as fagi fagi and considered as lectotype of Eumenis fagi genava did not at all belong to one of the two males of the syntype series of genava in the FrUHSTORFER collection. Although KUDRNA disposed of only one single (!) usable genital preparation and despite of his ignorance about the characteristic features of genava, he concluded that he had correctly attributed the prepared genital armature to his hermione.

A rail trip to London for purpose of inspecting the type series of genava in the FruHSTORFER collection: On 15.11.2015, I went to London to examine with my own eyes the syntype series of $H$. genava. On 16.11.2015, Peter RuSSELL received me in front of the BMNH where we both were received by Blanca HUERTAS, successor of the former conservator Phil ACKERY, with responsibility on the butterfly section of the BMNH. FrUHSTORFER's syntype series consisted from $2 \hat{\jmath}, 7$ 우 of $H$. genava from the Valais, all individuals dating 1905. Wing shape and pattern of both males were of a very typical, average appearance of genava. The abdomen of one specimen had been separated for preparation by Phil ACKERY. The females also, being less easily distinguishable in general than males of genava, represented perfectly the third Grayling species. In fact, the only available genital preparation of one of the two males had a genital armature resembling somewhat that of alcyone (KUDRNA's hermione in the narrow sense) but with appearance laying inside the range of variation of male genitalia of genava. The approximately 60 examined preparations of male and female genitalia of different Grayling species mainly from the collection of the Zoological Museum Amsterdam I had brought to Guido VOLPE years ago for preparation and photography visualized in an impressive way that even genitalia underly wide discrepancies, overlapping effects and malformations. LAFRANCHIS et al. (2015) confirmed this fact. Therefore, the determination of Graylings demands always the examination of characters of shape and pattern of wings. KUDRNA was apparently incapable of doing this. Therefore, his diagnosis has to be considered as being without any solid basis and is recommended to be rejected.

Larger series of faultless separated specimens of $H$. alcyone und genava in London and Strasbourg: In reviewing the inventories of Graylings in the collections of the aforementioned museums, I met there by the majority a more or less orderly mess with numerous confusions except for two cases. In company with Peter Russell, I controlled also the stocks of the Rock Grayling in the general collection of the BMNH on 15.11.2015, housed in an insect box with double glazing allowing to see easily the preparations from both sides. This box comprised two neatly separated series of Grayling individuals consisting of approx. 30-50 faultless determined individuals of $H$. alcyone and $H$. genava each. On 28.11.2009, I visited the "Musée zoologique de la ville de Strasbourg" where I was supervised by Christophe BRUA. Here, I came across the collection of Gilbert VARIN, author of the treatise "Les sous-espèces françaises d'Hipparchia fagi Sc., alcyone D. \& S. et neomiris God.", fortunately being left in the original state. VARIN's collection comprised larger series of $H$. alcyone (for instance his ssp. sogdiana faronica from SE France) and of $H$. genava. Even VARIN separated in a perfect way all his individuals of the two species 

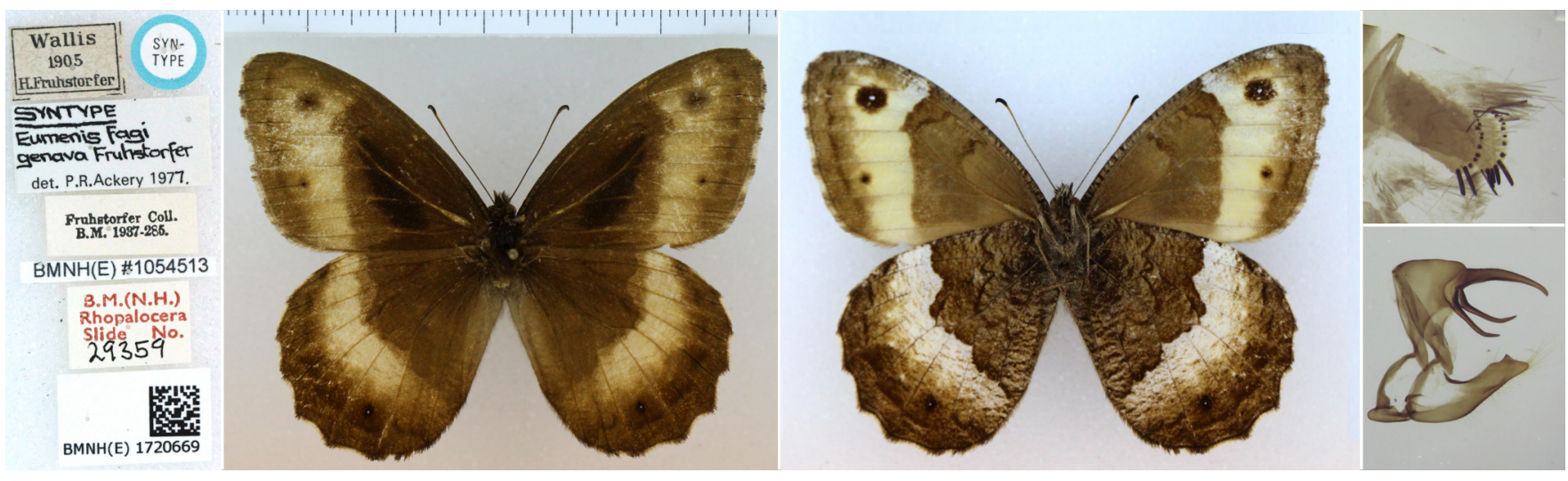

Fig. 9. One of the two males from both sides of Hipparchia genava of the syntype series in the FRUHSTORFER collection at the BMNH with labels and genital armature prepared by Phil ACKERY. Photographs John TENNENT, 25.03.2015

in collection. He was only missing sound foundations enabling him to recognize in his local forms the two species alcyone and genava.

Need for determination a neotype series for Hipparchia alcyone ([DENIS \& SCHIFFERMÜLLER], 1775): in his treatise "On the 'Wiener Verzeichnis', its authorship and the butterflies named therein", KUdRNA (2005, p. 14) commented his "Papilio alcyone [SCHIFFERMÜLLER], 1775" as follows: This name is considered available; it is invalid as it is a junior subjective synonym of "Papilio hermione LinNAEUs, 1764". This was KuDRnA's way to express that priority has to be attached to his personally favorite name hermione (L., 1764) over the more recent name alcyone (D. \& S., 1775). However, he was silent about the fact that the name hermione to designate the Rock Grayling was unjustified because his lectotype specimen in the Linnaean collection cannot be allocated to the collection of Queen Ulrika as, up to now, a hermione specimen was not in the collection when it arrived at Uppsala. This lectotype specimen came to light only when it was mentioned for the first time in "Revision of the Linnean Types of Palaearctic Rhopalocera" by VeRITY (1913) who detected it in the Linnaean collection approximately 125 years after it was sold to J.E. SMITH in London. Interestingly, LINNÉ's former student THUNBERG deposited hermione in his personal collection with four specimens of $H$. fagi (see fig. 3). Higgins and Riley (1978) as well as Peter RuSSELl queried KudRNA's arbitrary link of his lectotype specimen labelled hermione to this reference. In my view, the right to exist of the name hermione (L. 1764) is standing on very insecure foundations and does not at all stand up to actual scientific requirements. Therefore, some authors of prominent publications consequently refused up to now the reuse of the name hermione. The best will be to use furthermore the name alcyone (D. \& S., 1775) as it was specified by Hemming (1960) to design the species I have identified in numerous rearing experiments as Hipparchia alcyone (D. \& S., 1775), with the inclusion of Vienna and Lower Austria as its type locality. $H$. alcyone is sufficiently and unmistakably characterized by the historic figures given by Rösel vON Rosenhof (1755, vol. 3) (see figs 6ab), what SCHIFFERMÜLLER (D. \& S., 1775) is referring to, but also by the figures published later by HüBNER (1800) (see figs 7ab) being based probably on individuals with origin from the Vienna district. If the application of engraved coppers should no more be accepted, the determination of neotypes based on specimens in collection with origin from the Vienna region is recommended. By reason of the destruction of the SCHIFFERMÜLLER collection in 1848, original type material no longer exists since then. Collected and prepared material of $H$. alcyone from Vienna was traded in the past and should be available widely spread in collections of museums, not only in Vienna but certainly also in the collection of the BMNH. With regard to future research projects with the Grayling group, an undisputed and precisely defined type locality still inhabited with nominal alcyone should be the best.

Need for determination a type series for Hipparchia genava (FrUhSTORFER, 1908): What about the syntype series of genava in the FRUHSTORFER collection at the BMNH, KUDRNA wrote that he had correctly attributed the second male of the type series of genava in the FRUHSTORFER collection (see fig $9 \mathrm{ab}$ ) to his $H$. hermione Linnaeus, 1764, based on its genital armature. Indeed, KUDRNA was incorrect with his assignment of FrUHSTORFER's genava to his hermione (L., 1764) because the lectotype specimen in the Linnaean collection represents, within the personal meaning and that of LeRAUT (1990), the species $H$. alcyone (D. \& S., 1775) but not $H$. genava (FRUHST., 1908). Further syntypes of genava collected by FrUHSTORFER would most probably be found also in the collection of the "Musée d'Histoire naturelle de Genève", where I came across some preparations of Erebia styx labelled FrUHSTORFER more than 20 years ago. Hans FruHSTORFER was a German dealer of insects and shells inhabiting a house in Geneva from 1905 until his death in 1922 (see JUTZELER, 2006). With regard to future studies of the Grayling group, a precisely defined type locality such as the central Valais with Stalden at 2,5 km SSE of Visp (as indicated by FRUHSTORFER himself) or Ausserberg 
at 3,5 km NW of Visp respectively being still well inhabited with genava would facilitate the best future research projects in the field with the Grayling group.

Making available personal image material: Because of the difficulties with KUDRNA, it became clear to me that the resistance by specialist circles to resolve the Grayling problem could only be overcome with great difficulty because specialists working for institutes with dependence on public resources are forced to use the species names with official validity. Therefore, hardly anyone of them would incur the risk to use alternative names. Where this situation led is witnessed for instance in the "Distribution Atlas of the Butterflies and Zygaenidae of Germany" (REINHARDT et al. 2020). In a rule-consistent way, the Rock Grayling is treated there under KuDRNA's problematic name "hermione LinNaEus, 1764" and "genava FrUHSTORFER" mentioned as a subspecies of it with distribution from Switzerland to Southern Italy, the author's name FrUHSTORFER being completed with the wrong date 1907 instead of 1908, a mistake copied, for lack of personal review, from KUDRNA's faulty "Revision". The fact that authors of prestigious works are forced to assume the outdated and faulty information in KUDRNA's "Revision" which can hardly be eradicated is an unfortunate side effect. The problem was discussed with Josef SeTtele, one of the co-authors of above-mentioned book.

Finally, I realized that an important chance was lost to dissolve once this imbroglio without providing my evidence to the public. A whole ring binder filled with 15-20 years old Kodachrome slides documenting in a unique way many of the rearing experiments on my balcony with the different Grayling series (Hipparchia fagi, genava, alcyone, syriaca) stored in my apartment. As all these photographs were not accessible to anybody, I invested private funds in the scanning, illustration and commenting them in the bibliographies of the three European Grayling species being uploaded on the Website of Tristan LAFRANCHIS' book publishing business (Google: Diatheo Lafranchis) under "La Vie des Papillons". These detailed and illustrated bibliographies enable interested lepidopterists to retrieve immediately detailed information and reproduced illustrations of importance. Moreover, they helped me to limit the present article to the main essentials.

\section{Abstracts being based on the bibliographies with Tristan LAFRANCHIS (alc bib A/B, gen bib, fag bib)}

Hipparchia alcyone (D. \& S. 1775) (alc bib A, p. 1-28 and B, p. 1-15): This species occurs in isolated populations from Russia to Spain within two disjunct areas (KUDRNA et al. 2015, see alc bib A, p. 21). It is characterized by an enormous local but also individual variation becoming especially noticeable in the Pyrenees and on the Iberian Peninsula. Caterpillars of $H$. alcyone representing a central European type with regard to their colour have been examined in rearing experiments with material from Senftenberg (Lusatia, southern Brandenburg, alc bib B, p. 2), Druskininkai (Lithuania, alc bib B, p. 1), Vernet-les-Bains (Eastern Pyrenees, alc bib A, p. 17) as well as from the outskirts of Vienna (Vienna and Lower Austria, alc bib A, p. 9). The reared caterpillars from central Spain (alc bib B, p. 7) and Andalusia (alc bib A, p.13) were of a dark colour with much contrast. On the other hand, the caterpillars from the French central Pyrenees (alc bib A, p. 11) had an extremely contrasting pattern with black and white lines, never observed in any other rearing series. All the caterpillars with some colour contrasts in the $5^{\text {th }}$ instar had marked subdorsal lines, a characteristic emphasized on the caterpillar of $H$. alcyone figured by ECKSTEIN (1913-1923). Several rearing series of $H$. alcyone produced final instar larvae, in which the head stripes were variable, sometimes completely coalesced on the head capsule (see alc bib A, p. 14, 19 \& alc bib B, p. 4).

The common characters of all the populations of alcyone are features of male genital armatures; in general: high number of Jullien rods set on broad platelets, under edge of valves strongly bent (see alc bib A, p. 1, 5 and $2^{\text {nd }}$ part, pl. 4-9), caterpillars of stocky shape with rather short and close cremaster tips (see alc bib A, p. 10, 15, 18, 19 and alc bib B, p. $1,4,5,7,8)$ as well as similarities in some wing characters $\left(\right.$ see $2^{\text {nd }}$ part). From the references of BoIsDuval (1832-34) and Duponchel (1832-35) (alc bib A, p. 1,2), it appears that the presence of this species in the surroundings of Marseille was known since the 1830's (see also the distribution maps created by T. LAFranchis in "La Vie des Papillons" and on his Website - Google: Diatheo Lafranchis). In south-eastern France, H. alcyone occurs in isolated populations in the zone of pre-alpine hills near the Mediterranean, being replaced by $H$. genava in higher altitudes. Probably because of the absence of H. genava from the whole Pyrenean chain, $H$. alcyone occupies there habitats at elevated altitudes, namely in the wetter central Pyrenees as ssp. pyrenaea OBERTHÜR, 1896, a local form being distinctly different from the geographically separated nominate form of alcyone occurring in the dryer eastern Pyrenees.

Tom Nygaard KRISTENSEN made available photographic material of $H$. alcyone from the Serranía de Cuenca (Castile) (alc bib B, p. 6) and from the Andalusian mountains (alc bib B, p. 8-11) and Helmut HötTINGER of $H$. alcyone and its habitat in the Steinfeld region near Wiener Neustadt (Lower Austria) (alc bib B, p. 13-15) showing perfectly the large local and individual variability of the underside wing pattern. Therefore, this species is by no means defined by only one single lectotype specimen as KUDRNA (1977) thought.

http://diatheo.weebly.com/hipparchia-alcyone.html http://diatheo.weebly.com/uploads/2/8/2/3/28235851/ hipparchia_alcyone bib.pdf

http://diatheo.weebly.com/uploads/2/8/2/3/28235851/ hipparchia alcyone complement.pdf

Hipparchia genava FRUHSTORFER, 1908 (gen bib, p. 1-34): this species populates hilly and 
mountain areas in Italy, in the eastern part of France and in the West of Switzerland (see the modified distribution map under KUDRNA et al. 2015, gen bib, p. 12). H. genava does not occur in pronounced local forms as does $H$. alcyone, but its individual variation is nevertheless large in particular on the underside of wings (see the different photographs exposed in gen bib p. 1, 7, 13, 14, 15 and the series of collected material from the Valais in coll. H. BIERMANN, gen bib p. 25-30). Caterpillars were examined originating from many rearing series: Calabria, Campania, Tuscany, southern Piedmont, south-eastern France, the Central massif, the Valais as well as from the Jurassic region near Bâle. They all showed a uniformity of colour varying in a similar way and without showing local characters (see gen bib p. 4). In comparison with $H$. alcyone, caterpillars of $H$. genava were of slender shape, with their cremaster tips being well separated and a head capsule with never coalescent stripes. Using the character of well separated cremaster tips, the caterpillar of the Rock Grayling, figured by BINK (1992) (gen bib, p. 1) under Hipparchia hermione (L.) with origin from Southern France, could thus be identified as belonging to $H$. genava.
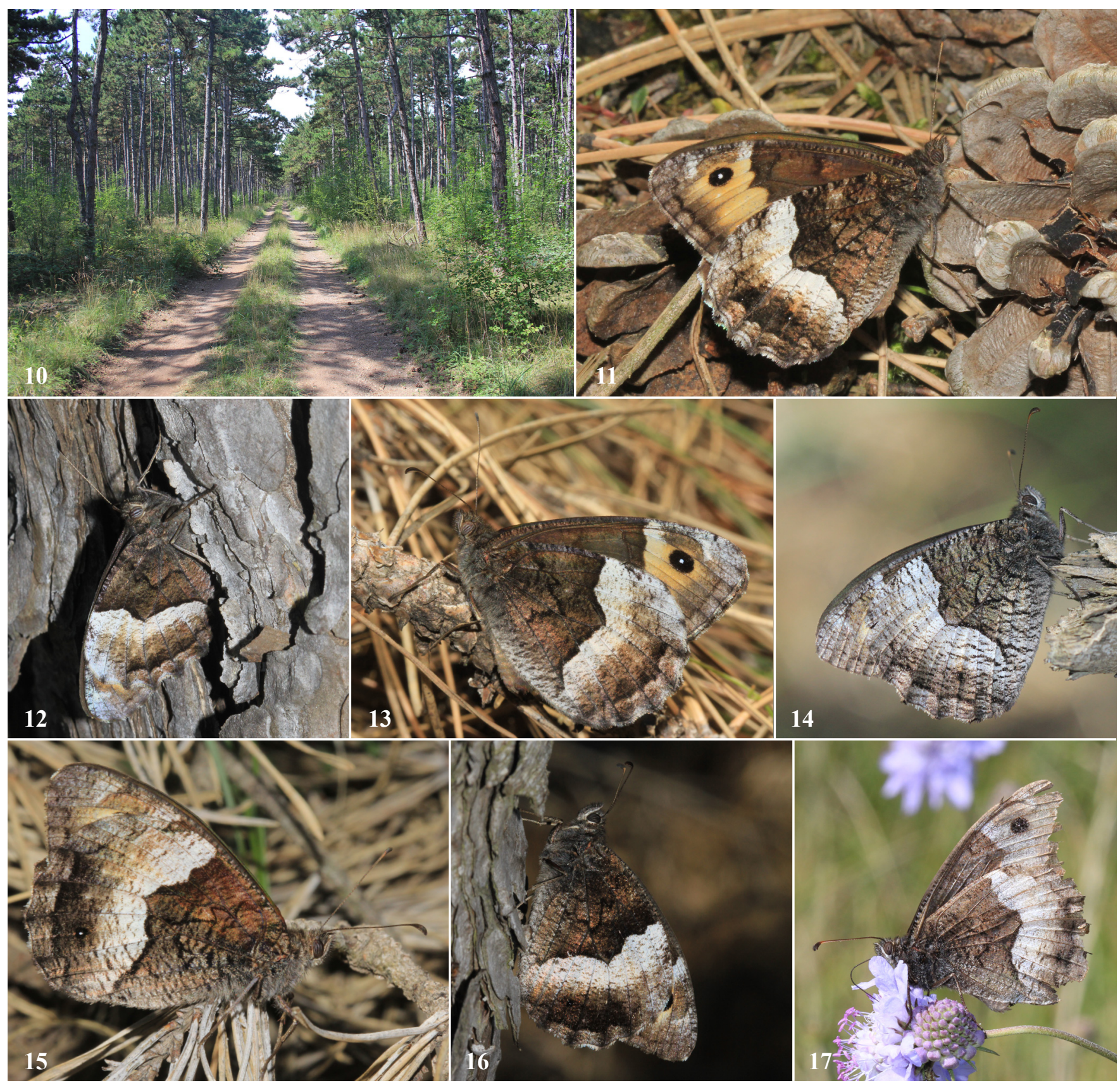

Figs. 10-17. Hipparchia alcyone (D. \& S., 1775) in the Steinfeld region (Lower Austria) by Helmut HöTTINGER. 10. On 17.07.2011 (figs. 10-16) as well as on 11/12.08.2011 (fig. 17), Helmut HöTTINGER visited the Military training area near Grossmittel in the Steinfeld region (Lower Austria) being situated near Wiener Neustadt or about $25 \mathrm{~km}$ south of Vienna City respectively, with intent to document $H$. alcyone inhabiting there the districts of light Black pine forest (in particular the waysides and trenches) comprising their marginal sectors avoiding however the open dry meadows as well as the ruderal sites (alc bib B, p. 13-15). The visited sites are a part of the "Domain Natura-2000 Steinfeld" whose access demands an exceptional administrative authorization. 11-17. The male and female individuals of the Viennese Rock Grayling photographed in the Military area near Grossmittel show in an impressive way the wide range of variation of their underside design. Photographs Helmut HöTtINGER 


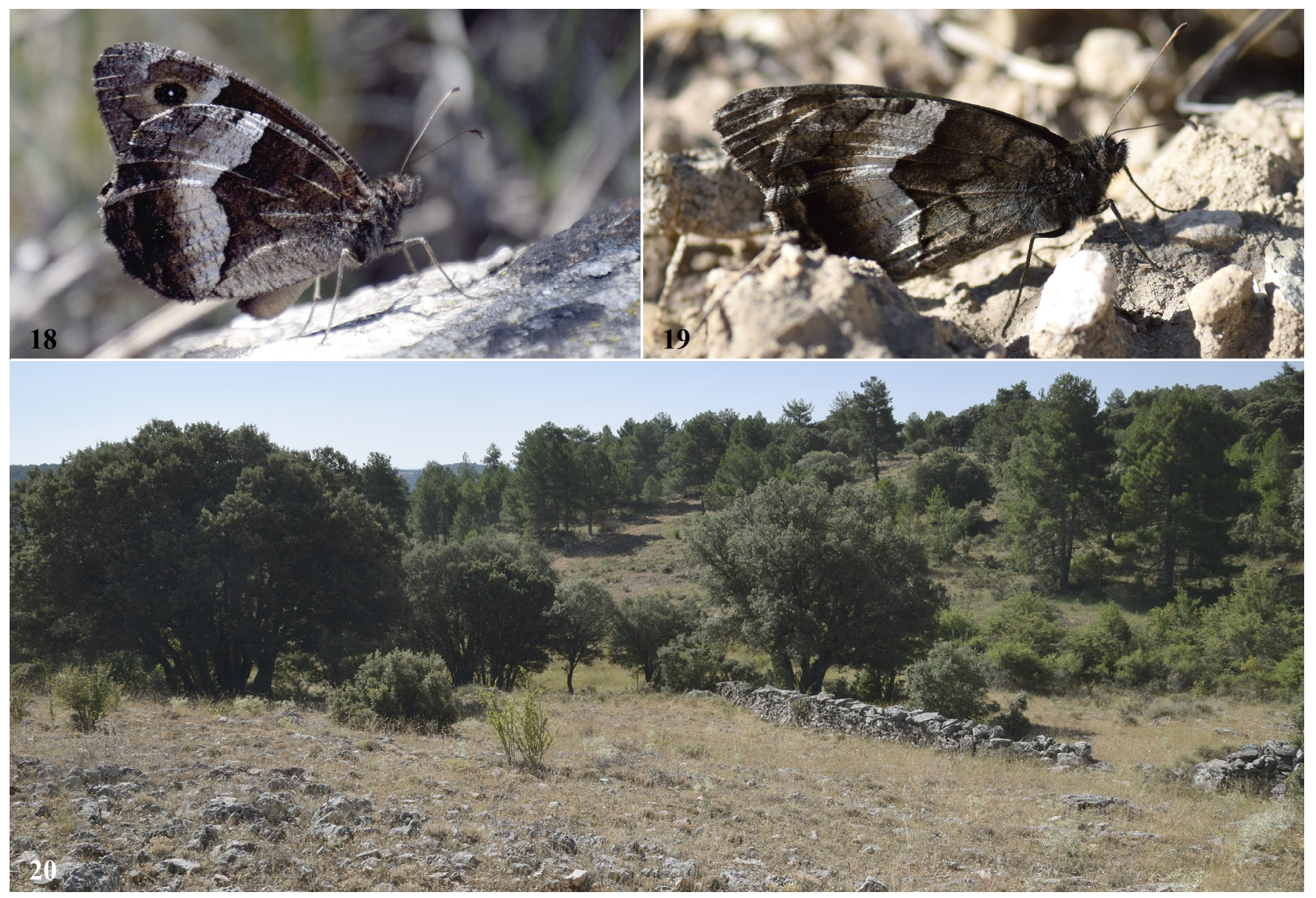

Figs. 18-20. Hipparchia alcyone, Serranía de Cuenca (Cuenca). 18. Male, 1.08.2016. 19. Female, 31.07.2016. 20. Habitat, 1.08.2016. Photographs Tom Nygaard KRISTENSEN
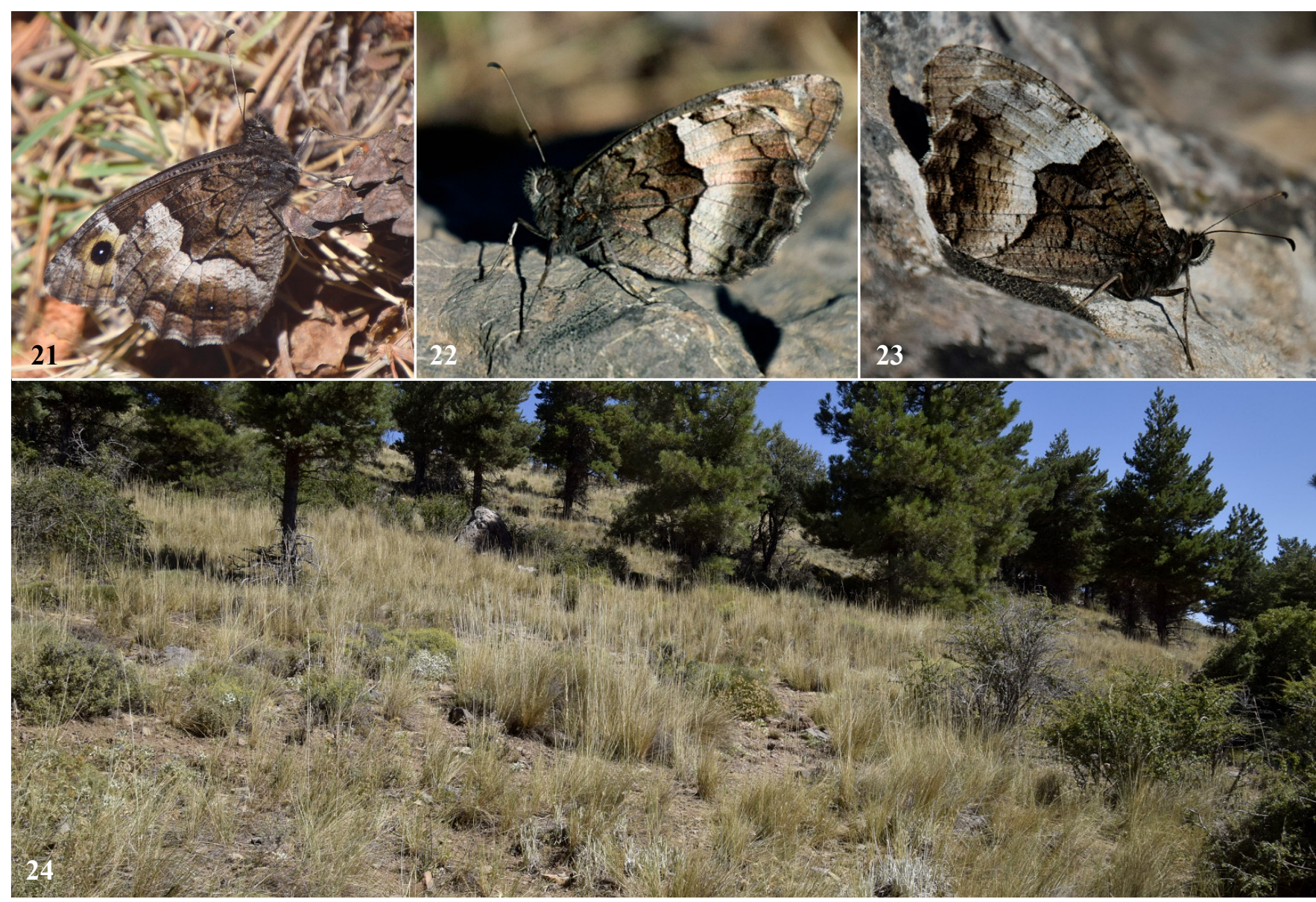

Figs. 21-24. Hipparchia alcyone, Sierra de Baza (Granada). 21. Male perching on a pine cone, 5.08.2016. 22. Another male (?). 23. A female perching almost invisibly on a rock, 7.08.2016. 24. Habitat, 5.08.2016. Photographs Tom Nygaard KrisTENSEN 

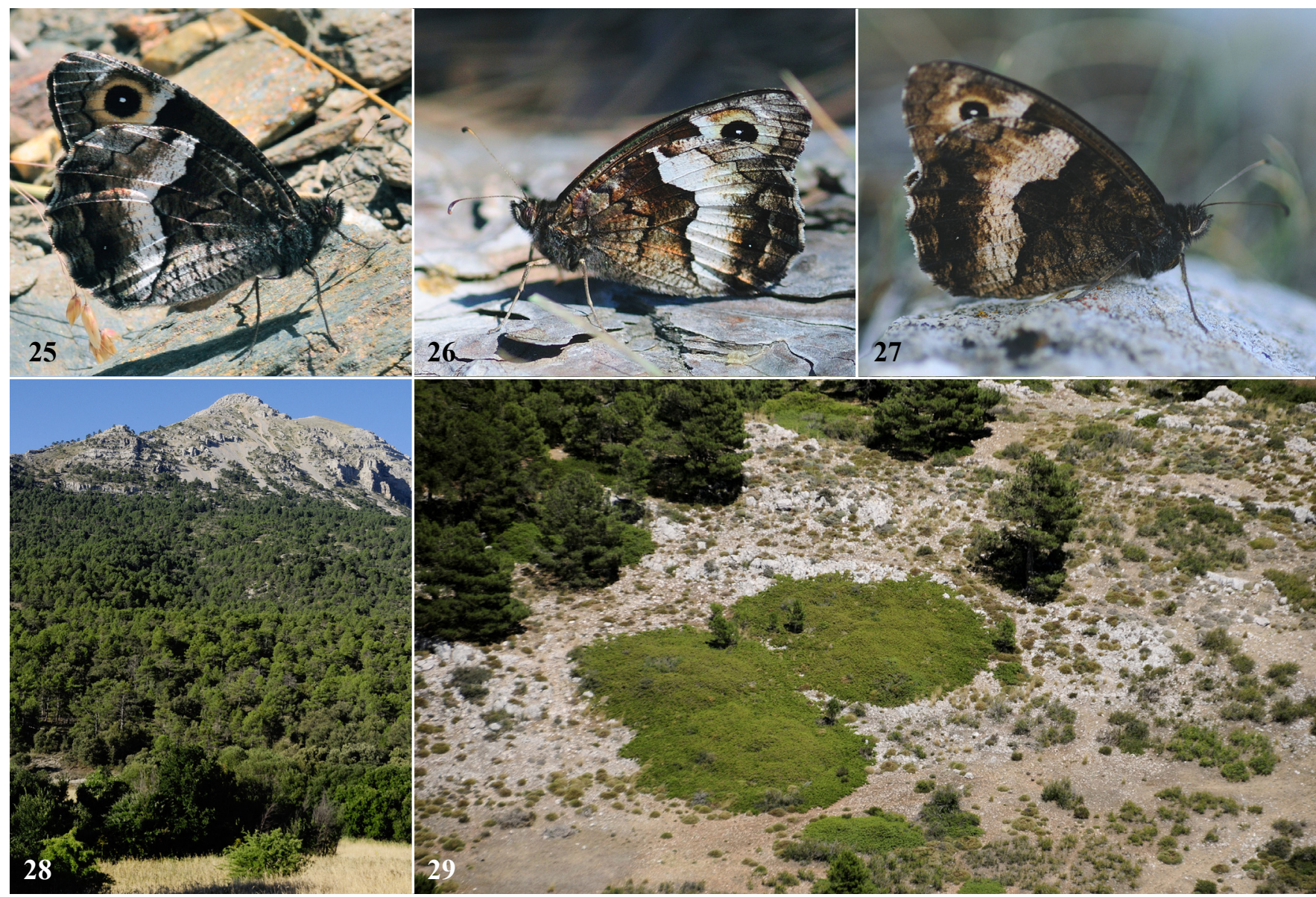

Figs. 25-29. Hipparchia alcyone, Sierra de Sagra (Granada). 25. Male on stony ground, 13.07.2014. 26. Female on a piece of bark, 12.07.2014. 27. Further female (?), 12.07.2014. 28, 29. Summit zone of Sierra de Sagra covered with a light pine forest on the lower slopes, 12.07.2014. Photographs Tom Nygaard KRISTENSEN

In his "Revision" of 1977, KUDRNA figured under $H$. hermione (L. 1764) a genital armature of a male from Digne and a Jullien organ from Aspromonte, both being characteristic of $H$. genava, to say the inferior edge of valves being less bent than in alcyone and the Jullien organ with intermediate number of rods set on a some convergent platelet. Apparently, KUDRNA was not aware of the fact, that preparations of his figures 86 and 87 belonged to a species other than that of the lectotype specimen in the Linnaean collection in London labelled hermione (see KUDRNA 1977, gen bib, p. 11). In the older literature, there are some figures of imagines of $H$. genava in VERITY's $5^{\text {th }}$ volume (Satyridae) of "Le Farfalle Diurne d'Italia" (1953, plate 73, figs 12-37) being treated there under "aelia HofFMANSEGG, 1804", name validated by HEMMING in 1943 instead of alcyone and rejected again by the same author in 1960. VERITY didn't confuse those specimens with the similar species $H$. fagi, contrary the study published by SBORDONI et al. (2018), a reference being supplemented with a critical review (see alc bib A, p. 26 and gen bib, p. 14). In the taxonomic literature comprising KUDRNA's "Revision" and Tolman and Lewington (1997), all the figured Grayling species represent the species $H$. alcyone and $H$. fagi whereas $H$. genava is completely lacking. Due to the lack of a trustworthy illustration, unfortunately, TSHIKOLOVETs (2011) illustrated Hipparchia genava (FrUHSTORFER, 1907 instead of 1908) by figuring
3 specimens originating from Marseille, which are clearly $H$. alcyone.

Stimulated by a discussion recorded by Culot (1905) with members of the Lepidopterological Society of Geneva concerning the existence of an intermediate Grayling form in the Valais, FRUHSTORFER $(1908,1910)$ initiated a research program with John Jullien published in "Entomologische Zeitschrift, Frankfurt a. M." The Valais Rock Grayling was recognized there for the first time as a local form named by FRUHSTORFER (1910) Eumenis alcyone genava. FRUHSTORFER's diagnosis expresses only that this form was considered by him as being more closely related to $H$. alcyone from the Vienna region with regard to its Jullien organ with a higher number of sticks than to $H$. fagi with no more than 3-4 sticks set on a narrow shaped Jullien organ. In collections and older publications, individuals of the appearing of $H$. genava are quoted partly under "hermione" (within the meaning to represent fagi) and partly under $H$. alcyone (within the meaning to represent the smaller Grayling species).

Mario RAviglione made available some photographs of $H$. genava and its habitat on the Mont Salève, considered as Geneva's own mountain. This site could be the place which FruHSTORFER (1908, 1910) meant by "Geneva" in his survey. Furthermore, some photographs are presented resulting from an excursion on the top of mount Holzfluh (734 m) 
near Balsthal (Solothurn Jura, $\mathrm{CH}$ ) carried out on 27.07.2020 with Stephan Bosshard. A further series of photographs was taken above Ausserberg (Valais, $\mathrm{CH}$ ) during trips by Stephan BossHARD as well as on a joint trip with David JUTZELER on 17.07.2021.

http://diatheo.weebly.com/hipparchia-genava.html http://diatheo.weebly.com/uploads/2/8/2/3/28235851/ hipparchia genava 730 bc 20201007 ok.pdf

Hipparchia fagi (SCOPOLI, 1763) (fag bib, p. 1-18): it was shown by an extensive rearing programme that the two species, Hipparchia fagi and H. genava, have clearly distinct caterpillars whereas their imagines tend to have common characters of wings with tendency of similar variations. In practice, the separation of these two species often causes much more problems, particularly in Italy and France, than the separation of $H$. alcyone from $H$. genava which can approach or even overlap each other on very limited points in southern France only. The study about the distinction of $H$. fagi and $H$. genava in Campania (VOLPE and JUTZELER, 2001, see fag bib, p. 11) has shown that $H$. fagi is a species with a centre of distribution at lower altitudes and $H$. genava at medium altitudes and that the two species commonly occur in the Apennines within a large overlapping altitudinal zone. A comparable situation exists also in France, easily seen from a comparison of their distribution maps on the Website of "La Vie des Papillons" (Google: Diatheo Lafranchis) as well as on page 726 of this book (LAFRANCHIS et al. 2015). The caterpillars of $H$. fagi observed from several rearing series from Campania and the Monti Aurunci (above Formia, Latium) tended to be darker in colour compared with reared material from several sites in France (for instance Bollenberg, Haut-Rhin) or also from Kalavrita (surroundings of Egio, Peloponnesus).The large variation of both sexes of $H$. fagi was demonstrated by Verity (1953, plate 72, figs. 32-41 and plate 73, figs. 1-11, see fag bib, p.
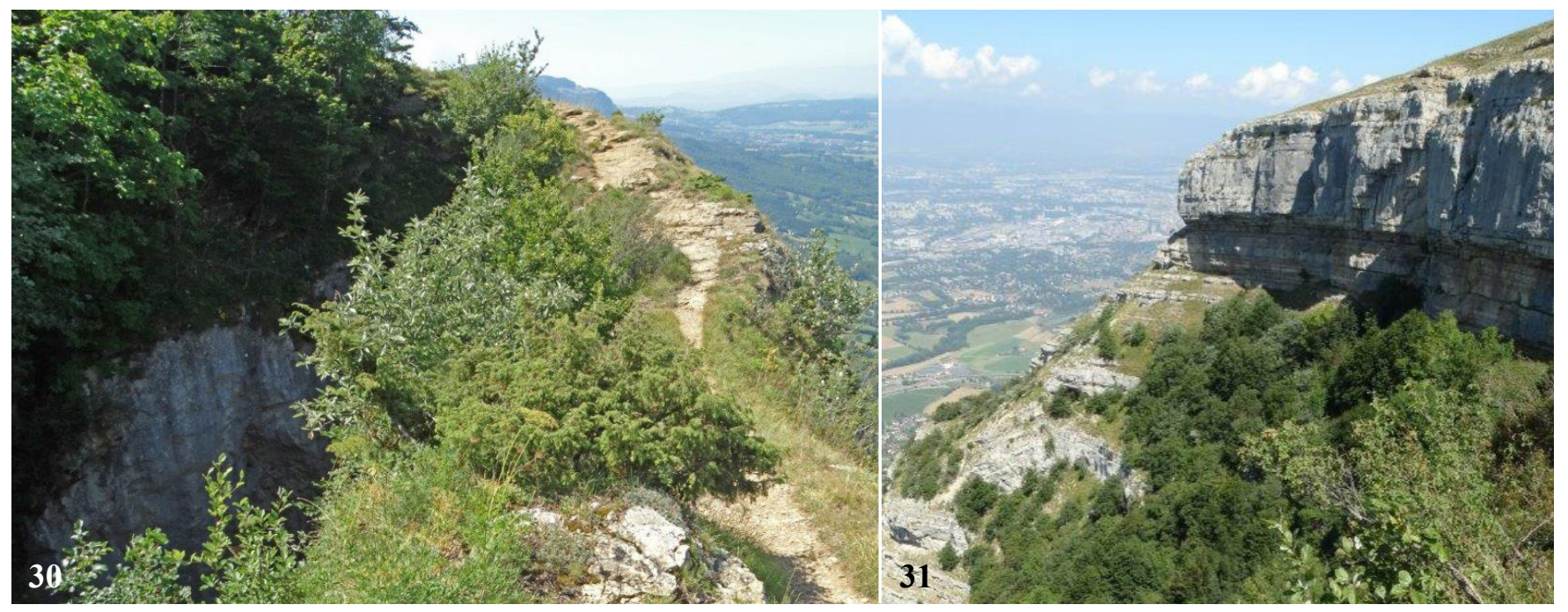

Figs. 30-31. Hipparchia genava localities on the Mont Salève (see gen bib, p. 19-22). 30, 31. Rocky escarpment in the northwest of the Mont Salève with view on the outskirts of Geneva (31) and the adjacent plain (30), 24.07.2018. The occurrence of Hipparchia genava on Geneva's local mountain should have been eponymous since FrUHSTORFER (1908) commented his first description of "Eumenis fagi genava nov. subspec." in the Leipzig "Entomologisches Wochenblatt" as follows: "Patria: Valais, type from Stalden (near Visp); abundant also below Visperterminen and near Martigny. Males from Geneva appear likewise to belong to it". Photographs Mario RavigLIOnE
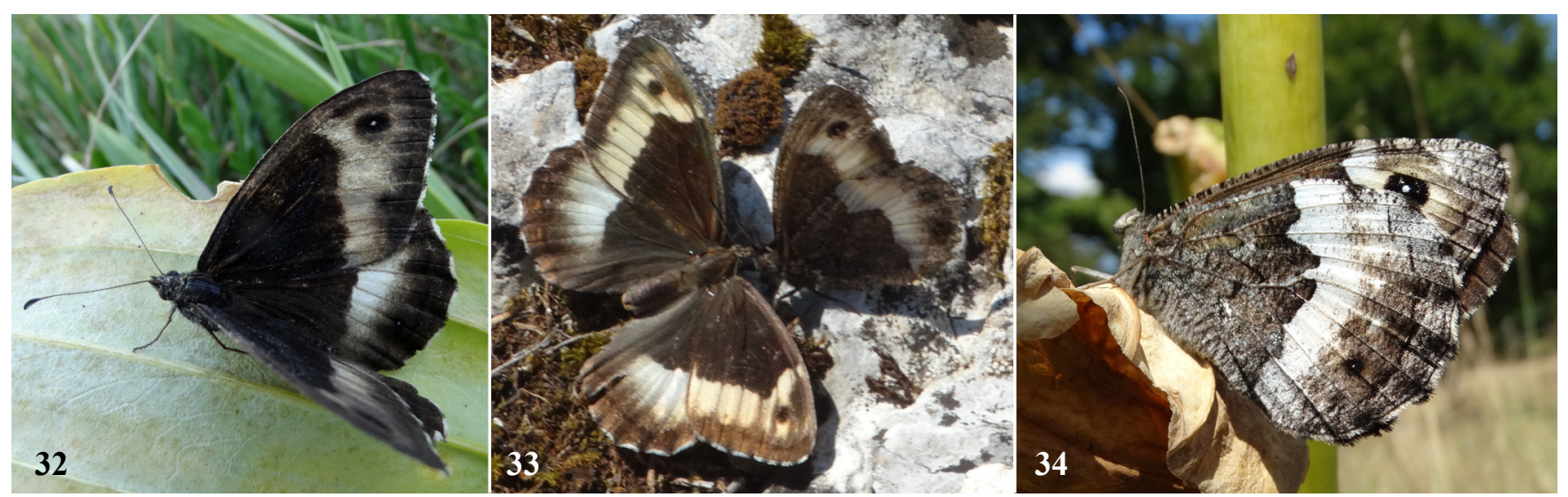

Figs. 32-34. Hipparchia genava on the Mont Salève. 32. Typical male with roundish wing shape, 24.07.2018. 33. Courtship of H. genava observed on 8.08.2019, the female perching with opened wings. 34. Female of H. genava, underside, 24.07.2018. Photographs Mario RavigLIONE 


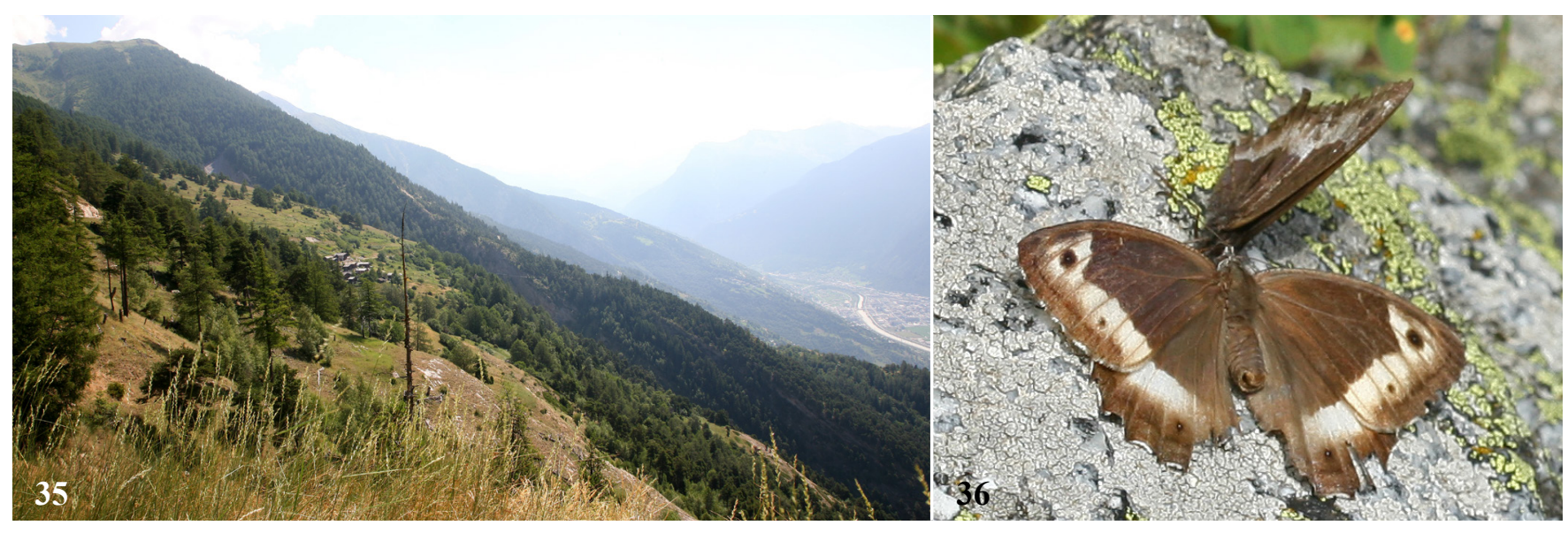

Figs. 35-36. Hipparchia genava, Ausserberg area. 35. View from Alp Leiggern (1628 m) above Ausserberg in south-eastern direction towards the zone of light pine forest and the village of Visp at the bottom of the central Valais, 21.07.2010. 36. Another courtship near Zeneggen situated about $6 \mathrm{~km} \mathrm{SSW}$ from Ausserberg, 13.08.2011. The female with opened wings resembles strongly a female of the Tree Grayling Hipparchia fagi, a species appearing to be extremely rare in the Valais with probable records on photographs taken in the region North of the Simplon summit. Above Ausserberg however, H. genava seems to be the only Grayling species being still rather abundant in the zones of pine forest up to the overlying zone of larch trees. Photographs Stephan Bosshard
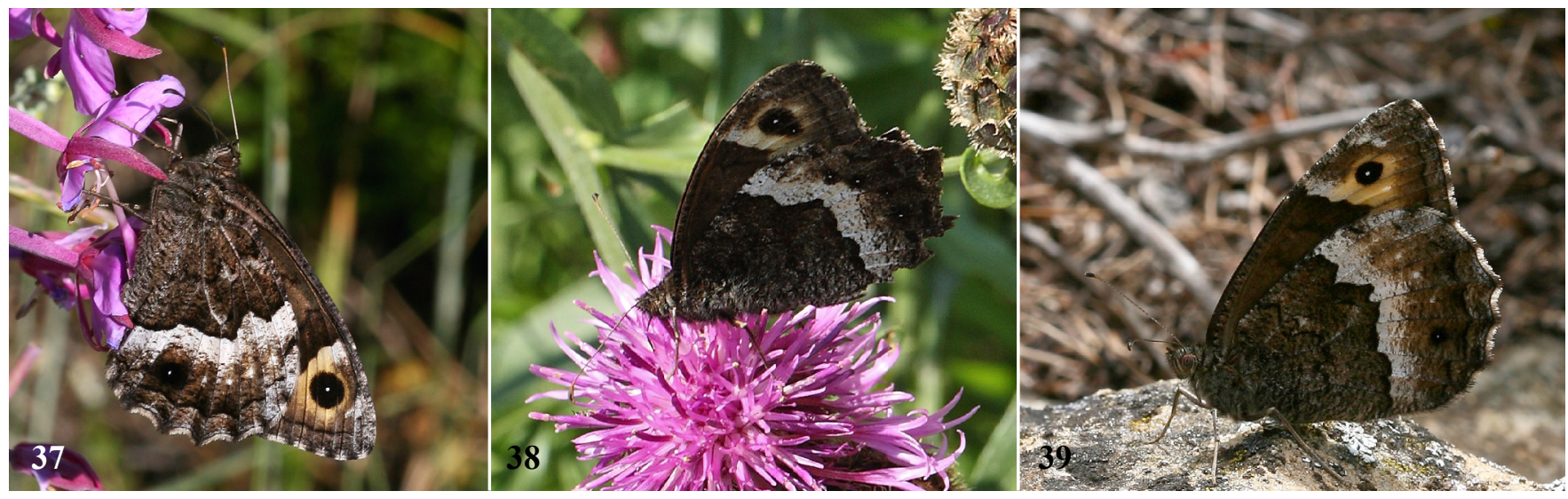

Figs. 37-39. Hipparchia genava, Ausserberg area. 37. Male of H. genava on Alp Leiggern (Ausserberg), 1628 m. 38 . Another male of $H$. genava with additional black ocelli on the hindwing, Alp Leiggern, $1349 \mathrm{~m}$. 39. H. genava female near Zeneggen, 27.07.2007. Photographs Stephan BosshaRD

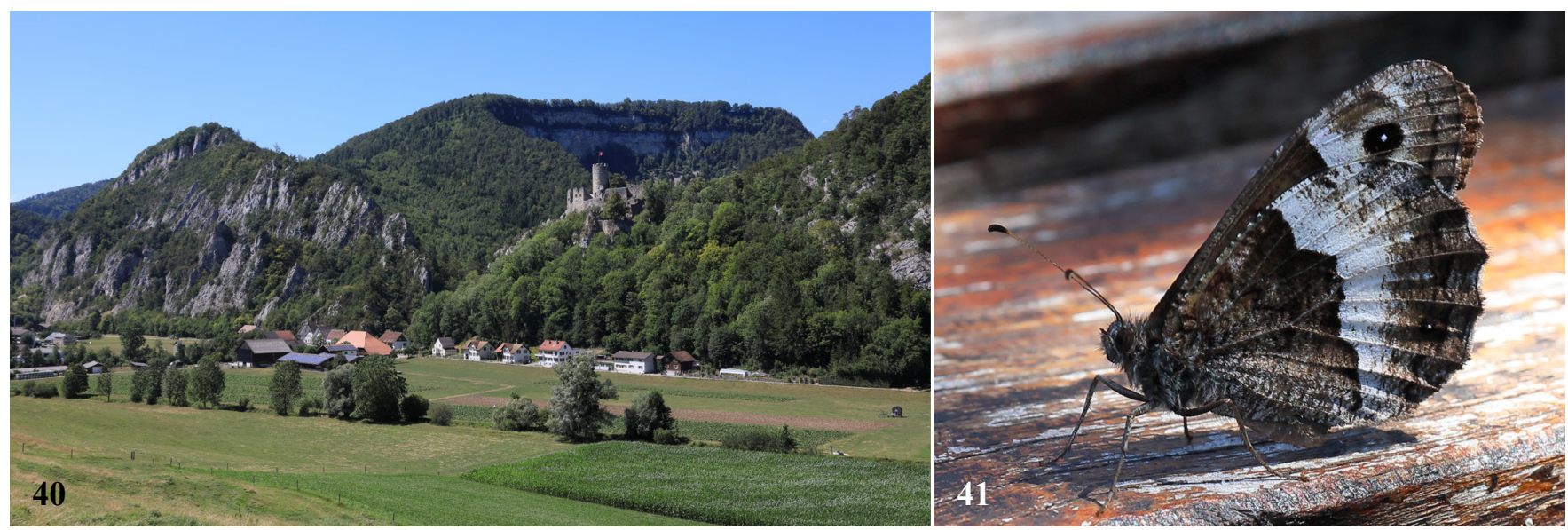

Figs. 40-41. Hipparchia genava, Holzfluh near Balsthal (see gen bib p. 22-25). 40. When I prepared the bibliography on Hipparchia genava for the Website of the book "La Vie des Papillons" (Google: Diatheo Lafranchis), I desired to visit once a marginal site of Hipparchia genava. On 27.07.2020, the local specialist Hans WITTMER was willing to lead Stephan BossHARD and myself to the top of the Holzfluh, a limestone hill towering over the village of Balsthal (ctn. Solothurn), belonging to the most northeastern sites of $H$. genava in the Swiss Jura. WiTTMER regularly recorded H. genava on the Holzfluh from $1977-$ 2011 , between the foot at $505 \mathrm{~m}$ and the top at $734 \mathrm{~m}$. At the occasion of this visit, the only specimens of $H$. genava were seen on the very small summit area (climatic warming?) where some individuals of both sexes circulated during a long time around the red bench seat. 41. Female perching on the bench seat on the top of this hill, 27.07.2020. Photographs Stephan BossHARD 

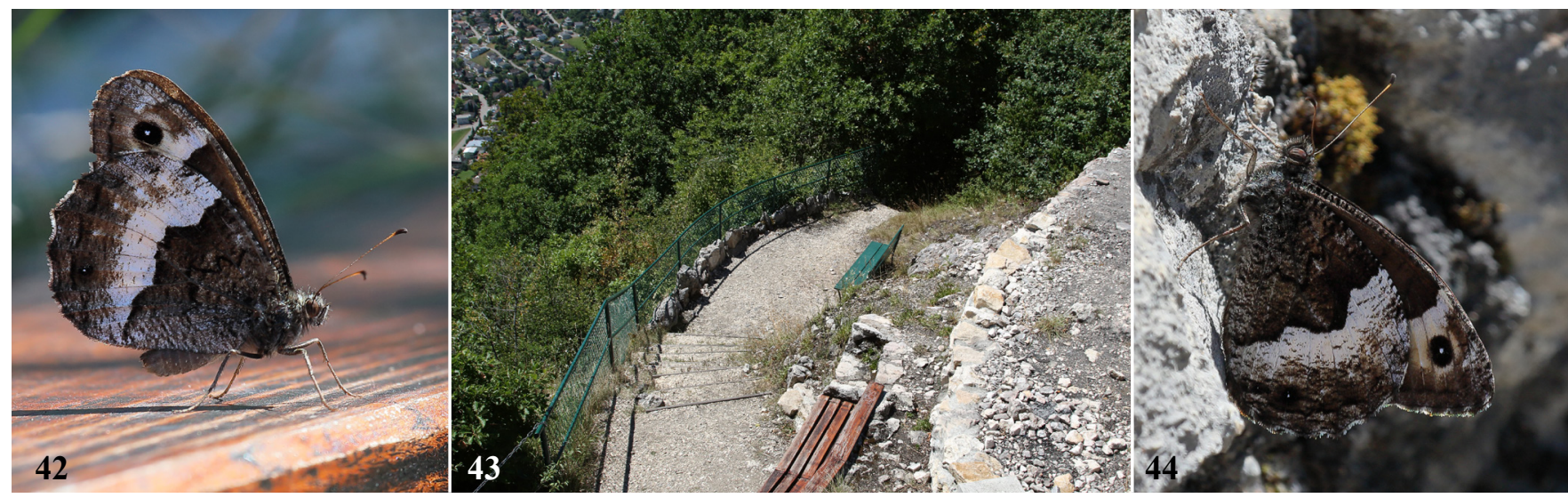

Figs. 42-44. Hipparchia genava, Holzfluh near Balsthal. 42. Male on the red bench seat. 43. Top of the Holzfluh with two bench seats and a fireplace (at right) for federal holiday being surrounded by thermophilus bushes anchoring in limestone gaps. 44. Another male of $H$. genava sitting on the limestone cuboids under the red bench seat. At this very limited place, we noted also the presence of further interesting hilltopping species such as Iphiclides podalirius (several specimens), Satyrium spini and Apatura sp. Photographs Stephan Bosshard

10). It can also be observed by the photographs shown in the bibliography with T. LAFRANCHIS of males from the Alsace and the Swiss Jurassic chain (fag bib, p. 8) and of reared adults from Kalavrita in the north of the Peloponnesus (fag bib, p. 14, 15).

Common features of all the populations of $H$. fagi are found on the male genital armatures (i.e. some larger than those of $H$. genava, Jullien's organ with 3-4 rods at most, set on a pointed, narrow plate, inferior edge of valves slightly angulated), on several characters of wings (see $2^{\text {nd }}$ part), but also the caterpillar cannot be mistaken neither with that of $H$. genava nor with that of $H$. alcyone. Throughout the literature, adults of both sexes of $H$. fagi are in general described and illustrated inadequately to be distinguished with certainty from individuals of $H$. genava. As a consequence of this situation, confusions between $H$. fagi and $H$. genava are to be found everywhere in the literature, in collections and on the Internet.

http://diatheo.weebly.com/hipparchia-fagi.html http://diatheo.weebly.com/uploads/2/8/2/3/28235851/ hipparchia fagi bib.pdf

Grayling problem solved? I consider the problem of the European Graylings existing already for 125 years (CULOT, 1905) as definitely solved in a satisfying way with regard to the practical systematics for field work, comprising a European Grayling group with the 3 species: Hipparchia alcyone ([DENIS \& SCHIFFERMüLlER], 1775), Hipparchia genava (FRUHSTORFER, 1908) and Hipparchia fagi (SCOPOLI, 1763) within the meaning of LERAUT (1990). For 15 years, LERAUT's model is in common use in Switzerland as well as in France and by the German Webside "Lepiforum". The crazy situation with KUDRNA's "Revision" is no longer reasonable neither for amateurs in the field nor for specialists. When I visited in the 1990 years KUDRNA's "Rhöner Symposium" in Oberelsbach (Bavaria), his vision was the unification of the lepidopterological nomenclature in the different European countries. The present article in collaboration with Peter RUSSELL is a contribution to approach this target also with the Grayling group.

\section{Acknowledgements}

I owe particular thanks to Peter Russel (GB-East Wittering) for his critical text review, linguistic control and scientific contribution. I came in contact with him in connection with his spectacular private research projects being dedicated to the species of the genus Hipparchia populating the islands of Macaronesia: this concerns the species of the group of Hipparchia wyssii CHRIST (1889) with presence on 5 of the 7 Canary Islands (see Linneana Belgica 20 (7), 2007, p. 9-44), Hipparchia maderensis Bethune-Baker 1891, occurring on Madeira (L.B. 19 (5), 2004, p. 197-208) and the 2 (3) species forming the group of Hipparchia azorina STRECKER (1899), with distribution on 7 Acores islands. The evaluation of the 9 rearing series of the azorina group took place during 2004, 2005 and 2007 in 5 parts (L.B. part 1.1: 19 (5), 2004, p. 197-208; part 1.2: L.B. 19 (7), 2004: p. 293-304; part 2.1: L.B. 20 (1), 2005: p. 3-14; part 2.2: L.B. 20 (7), 2007: p. 45-54; part 3: L.B. 20 (7), 2007, p. 55-74). As a revisor of the blocked precursor version of the present article from 2016 (2017), Peter Russell is familiar with the details of the problematics of the Grayling group.

Thanks are also due to Tristan Lafranchis (SP-Figueres, Catalonia) for his always encouraging and inspiring continually collaboration during more than 20 years, first in connection with my articles in Linneana Belgica from 1999-2006 followed by an intense collaboration in connection with his 750 pages comprising book project "La Vie des Papillons" (Google-Diatheo Lafranchis) from 2011-2015 (with detailed presentation of the Grayling problem according to LERAUT) and, for the common elaboration of numerous bibliographies from 2016 until now to be downloaded from his Website (Google: Diatheo Lafranchis), referring to the butterfly species dealt with in the above mentioned guide, among those the particularly detailed bibliographies on the three European Grayling species (see the links above).

For photographs of high quality and information, I thank also my friends and colleagues Helmut Höttinger (A-Vienna), Tom Nygaard Kristensen (DK-Brabrand), Stephan Bosshard (CH-Russikon), Hans Wittmer (CHOensingen), Mario Raviglione (CH-Geneva) and John Tennent (BMNH London). 


\section{Bibliography}

Aurivillius P.O.C. (1882) Recensio critica lepidopterorum Musei Ludovicae Ulricae quae descripsit Carolus A Linné. Kongl. Svenska Vetenskaps-Akademiens Handlingar 19 (5): 3-188, 1 coloured plate. [Papilio Hermione: p. 86].

https://www.biodiversitylibrary.org/ item/135426\#page/5/mode/1up

Balletto E. and Leigheb G. (2021) Otakar Kudrna 19392021, in Memoriam. Nota Lepidopterologica 44: 133-140.

BINK F.A. (1992) Ecologische Atlas van de Dagvlinders van Noordwest-Europa, $2^{\circ}$ druk. Schuyt, Haarlem. [Hipparchia hermione (= genava): p. 404-405]. gen bib: 1

BoISDUVAL J.B.A. [1832 (-1834)] Icones historique des Lépidoptères nouveaux ou peu connus; collection avec figures coloriées des Papillons d'Europe nouvellement découverts. 1. Rhopalocères. Roret, Paris. 251 p, 47 pl. [Satyrus Alcyone: p. 202-203; pl. 40, fig. 5, 6]. alc bib A: 1

CLERCK C.A. (1759 \& 1764) Icones Insectorum variorum cum nominibus eorum trivialibus locisque e C. Linnaei syst. Nat. allegatis, Holmiae. Section I, 8 pp., plates 1-16 (1759); Section II 8 pp., plates 17-55 (1764). [Section III, unpublished, original present in the Archives section, Center for History of Science, the Royal Swedish Academy of Sciences, Stockholm, Sweden].

https://gallica.bnf.fr/ark:/12148/bpt6k991488/f1.item https://gallica.bnf.fr/ark:/12148/bpt6k991488.image

Culot J. (1905) Satyrus Hermione et Alcyone. Bulletin de la Société Lépidoptérologique de Genève 1: 33-37. gen bib: 2

Denis M. and SCHIFFERMüLlER I. (1775) Ankündung eines systematischen Werkes von den Schmetterlingen der Wienergegend. Augustin Bernardi, Wien. 323 p. Die Tagschmetterlinge oder Falter $=$ Papiliones L.: $\mathrm{p}$. 158-187, 320-322. [Papilio Alcyone, Dunkelbrauner bleichgelbstreifigter Falter: p. 169]. alc bib A: 2

DUPONCHEL P.A.J. [1832 (-1835)] Histoire naturelle des Lépidoptères ou Papillons de France par M. J.B. Godart. Méquignon-Marvis, Paris. Supplément 1 (Diurnes). 466 p., 50 pl. [Satyrus Alcyone: p. 176177, pl. 26, fig. 1-2. Les figures montrent Hipparchia alcyone s.s.]. alc bib A: 2

ECKSTEIN K. (1913-1923) Die Schmetterlinge Deutschlands mit besonderer Berücksichtigung ihrer Biologie, Bd. 1-4. K.G. Lutz, Stuttgart. [Satyrus alcyone: vol. 1, p. 86; pl. 11]. alc bib A: 3

Forster W. and WoHLFAHrT T. (1955) Die Schmetterlinge Mitteleuropas, Band II, Tagfalter Diurna (Rhopalocera und Hesperiidae). Franckh'sche Verlagshandlung Stuttgart. [Hipparchia fagi: p. 38; pl. 10, figs 10 $\hat{\text {, }, 11}$, $13 \hat{\jmath}$ (Südtirol, Waidbruck and Klausen); Hipparchia aelia (= alcyone): p. 38-39; pl. 10, fig. $14 \hat{\jmath}, 15 \hat{\jmath}$ (Osnabrück)]. alc bib A: 4

FRUHSTORFER H. (1908) Lepidopterologisches Charivari. Entomologisches Wochenblatt, Leipzig 19 (25): 80-82. [Ssp. sigurdrifa, odilo and vipsania: p. 81]. alc bib A: 4

FRUHSTORFER H. (1908) Ueber ein neues Organ der Rhopaloceren. Entomologische Zeitschrift, Frankfurt am Main 12 (12): 50. alc bib A: 4

FRUHSTORFER H. (1908) Neues über das Jullienische Organ. Entomologische Zeitschrift, Frankfurt am Main 22 (24): 94-99. alc bib A: 4

FruHSTORFER H. (1910) Neues über Eumenis fagi und alcyone. Entomologische Zeitschrift, Frankfurt am Main 24 (14): 71-73, (15): 75-77, (16): 82-83, (17): 8688. alc bib A: 6
Hemming F. (1943) On the correct names of the species commonly known as Hipparchia hermione (L.) and $H$. alcyone (SchIFFERMülleR \& Denis) (Lep. Satyridae). The Entomologist 76: 57-58. alc bib A: 7

Hemming F. (1960) Determination of the precedence to be accorded to the specific names published for twenty nominal species of butterflies by Denis \& Schiffermüller in 1775 in relation to names published by other authors in the same year. Annotationes Lepidopterologicae, London, part 2, p. 43-72. [Papilio alcyone [Denis \& Schiffermüller], 1775 - Hipparchia alcyone ([Denis \& Schiffermüller], 1775): p. 47-48]. alc bib A: 7

Higgins L.G. and RiLey N.D. (1970) A Field Guide to the Butterflies of Britain and Europe, $1^{\text {st }}$ edition. Collins, London. 380 S., 60 plates, 371 distribution maps. [Hipparchia fagi: p. 137; plate 29, fig. 1 a, b; Hipparchia alcyone: p. 138; plate 29, fig. 2 a, b]. alc bib A: 8

Higgins L.G. and RILEY N.D. (1978) The Rock Grayling, Hipparchia alcyone (DENIS \& SCHIFFERMÜLLER, 1775) (Lepidoptera: Satyridae). Entomologist's Gazette 29: 51-52. alc bib A: 8

HofFMANSEGG J.C. GRAF vON (1804) Alphabetisches Verzeichniss zu J. HÜBNER's Abbildungen der Papilionen mit den beigefügten vorzüglichsten Synonymen. Magazin für Insektenkunde von Karl ILLIGER (edit.), vol. 3: 181-206. [Priority of the names by Linné: p. 182; Pap. Alcyone: p. 184; Pap. Hermione (=fagi): p. 194]. alc bib A: 8

HüBNER J. [1805 (1806)] Descriptions of "Die Schmetterlinge" (The Butterflies), Lepidoptera Linnéi, Glossata Fabricii, p. 1-74, with preface dating 21.12.1805 and list of contributors. [Description of Papilio Alcyone, Honiggrasfalter: p. 22. (see also the following reference). The descriptions of "The Butterflies" refer to the plates 1-124 in vol. 1 of Hübner's "Sammlung europäischer Schmetterlinge" (Collection of European Butterflies), Augsburg.].

HüBNER J. [1796-1838, dès 1827 (pl. 182, fig. 896) suivi par C. GEYER] Sammlung europäischer Schmetterlinge. Augsburg. 7 volumes (9 parts). Diurna (butterflies), $1^{\text {st }}$ volume. Hübner furnished descriptions of his "Butterflies" until plate 124 (fig. 636). The printed date of publication of the descriptions is 1805 , but they were available as printed matter only in 1806. [Papilio Alcyone, Honiggrasfalter: pl. 27 (1799-1800), fig. 125, 126. Description: p. 22]. alc bib A: 9

Jutzeler D. (2006) Confirmation de la dualité du "Petit Sylvandre" diagnostiquée par LERAUT (1990) - $3^{\text {ème }}$ partie: figuration d'Hipparchia alcyone Denis \& Schiffermüller (1775) et d'H. genava Fruhstorfer (1908) dans la littérature. Linneana Belgica 20 (6): 229233. alc bib A: 16

JUTZELER D. [2016 (2017)] Doubts about the validity of the species name Hipparchia hermione (Linnaeus, 1764) (Lepidoptera: Satyrinae) introduced by Kudrna (1977). Entomologica romanica 20: 5-56. Precursor article blocked by KUDRNA in 2017. alc bib A: 19

Jutzeler D., Lafranchis T., Olivares J. and Volpe G. (2002) Trois taxons du complexe d'Hipparchia alcyone (DENIS et SCHIFFERMÜLLER, 1776) en comparaison: ssp. vandalusica (sensu OBERTHÜR, 1894, nec LERAUT, 1990), ssp. pyrenaea (ОвеRTHür, 1894) et alcyone de l'Italie méridionale (Lepidoptera: Nymphalidae, Satyrinae). Linneana Belgica 18(6): 273-288. alc bib A: 10; gen bib : 4

JUTZELER D. and VolPe G., avec la collaboration de 13 lépidoptéristes (2005) Confirmation de la dualité du "Petit Sylvandre" diagnostiquée par LeRAUT (1990). $1{ }^{\text {ère }}$ partie: clarifications nomenclaturales et comparaison 
des stades larvaires d'Hipparchia alcyone Denis \& Schiffermüller (1775) et d'H. genava Fruhstorfer (1908). Linneana Belgica 20 (4): 145-160. alc bib A: 16

Jutzeler D. and Volpe G. (2006) Confirmation de la dualité du "Petit Sylvandre" diagnostiquée par LERAUT (1990) - $2^{\text {ème }}$ partie: comparaison des caractères alaires et des genitalia d'Hipparchia alcyone Denis $\&$ Schiffermüller (1775) et d'H. genava Fruhstorfer (1908). Linneana Belgica 20 (5): 193-206. alc bib A: 16

KudRnA O. (1977) A Revision of the Genus Hipparchia Fabricius. Classey, Faringdon. [Hipparchia hermione Linnaeus, 1764 (= alcyone \& genava): p. 24-31. alc bib A: 20

KuDRNA O. (2001) Miscellaneous notes on the taxonomy of four European butterflies (Lepidoptera: Rhopalocera): On the identity, status and type material of Eumenis fagi genava Fruhstorfer, 1907. Entomologist's Gazette 52: 255-258. gen bib: 12

Kudrna O. and BeliceK J. (2005) On the 'Wiener Verzeichnis', its authorship and the butterflies named therein. Oedippus 23: 1-32. alc bib A: 21

Kudrna O., Pennerstorfer J. and Lux K. (2015) Distribution Atlas of European Butterflies and Skippers. 632 p. Schwanfeld, Germany. [Hipparchia hermione (= alcyone \& genava): p. 466. alc bib A: 21

LAFrANCHIS T., Jutzeler D., KAN P. \& B. and GuIllosson J.-Y. (2015) La Vie des Papillons: Ecologie, Biologie et Comportement des Rhopalocères de France, 751 p. Diatheo, Paris. [Hipparchia fagi, genava, alcyone: p. 722-733]. alc bib A: 22

LEPIDOPTEROLOGEN-ARBEITSGRUPPE (1987) Tagfalter und ihre Lebensräume. Arten, Gefährdung, Schutz. Schweizerischer Bund für Naturschutz, Basel und Fotorotar AG, Egg ZH. [Hipparchia alcyone $(=$ genava $):$ p. $240-241$.

Leraut P. (1990) Contribution à l'étude des Satyrinae de France (Lep. Nymphalidae). Entomologica Gallica 2 (1): 8-19. alc bib A: 22

LINNÉ C. (1764) Museum S:æ R:æ M:tis Ludovicæ Ulricæ reginæ Svecorum, Gothorum, Vandalorumque (...) in quo animalia rariora, exotica, imprimis insecta \& conchilia describuntur \& determinantur prodromi instar editum. Salvius, Holmiae. [(Pap. N. G. Hermione: p. 281, $\mathrm{n}^{\circ}$ 99. Of the two references indicated under Papilio Hermione, "Pet. Gaz." (= Petiver, 1702-1706) refers to Hipparchia fidia and "Rös. Ins." (= RöSEL VON RosenHof, 1761) to Brintesia circe.]. alc bib A: 22

LinNÉ C. (1767) Systema Naturae per Regna Tria Naturae, secundum classes, ordines, genera, species (...) Laurentii Salvii, Holmiae. Tomus I, Pars II: 533-1327, Lepidoptera: 744-796. [Pap. Hermione: p. 773, n 149. Of the three references quoted under Papilio Hermione, "Scop. Carn." (= ScOPOLI, 1763) refers to Hipparchia fagi, "Pet. Gaz." (= Petiver, 1702-1706) to H. fidia and "Rös. Ins." (= RöSEL VON RoSENHOF, 1755) to $H$. alcyone. alc bib A: 22

OвERTHÜR C. (1894) Satyrus Alcyone, Hübner, forma Ellena, Obthr., forma Vandalusica, Obthr., forma typica, forma Pyrenaea, Obthr., aberr. Vernetensis, Obthr. Études d'Entomologie 19: 19-29; pl. 7. alc bib A: 24
Reinhardt R., Harpke A., Caspari S., Dolek M., KühN E., Musche M., Trusch R., Wiemers M. and Settele J. (2020) Verbreitungsatlas der Tagfalter und Widderchen Deutschlands, 568 Fotos, 218 Verbreitungskarten. Eugen Ulmer KG, Stuttgart (Hohenheim). [Hipparchia hermione (LinnAEUs, 1764), Kleiner Waldportier (syn.: H. alcyone): p. 336-337]. alc bib A: 26

RÖSEL VON RosENHOF A.J. (1746-1761) Der monatlichherausgegebenen Insecten-Belustigung 1. Theil (1746), 2. Theil (1749), 3. Theil (1755) und 4. Theil (1761). A.J. Rösel und C.F.C. Kleemann, Nürnberg. [Dunkelbrauner, ockergelber Wald-Papilion mit zweyen schwarzen Augen-Spiegeln in den Ober-Flügeln (=alcyone): Theil 3 (1755), p. 207-209; pl. 34, fig. 5, 6]. alc bib A: 26

Sbordoni V., Cesaroni D., Coutsis J.G. and Bozano G.C. (2018) Guide to the Butterflies of the Palearctic Region. Satyrinae part V, Genera Satyrus, Minois, Hipparchia. Editor: Gian Cristoforo Bozano, Milano. ISBN 978-9987989-22-9, ISSN 1723-459X. [Hipparchia hermione (=alcyone \& genava): p. 52-55]. alc bib A: 26

Scopoli J.A. (1763) Entomologia Carniolica, exhibens Insecta Carniolae indigena et distributa in Ordines, Genera, Species, Varietates Methodo Linnaeana. Typis Johannis Thomae Trattner, Vindobonae. 420 p, 43 pl. Lepidoptera: 142-258, pl. 16-36, Papilio (= Diurnes): 142-182. [Papilio Fagi: p. 152, $\mathrm{n}^{\circ} \&$ fig. 428]. fag bib: 9

Tolman T. and Lewington R. (1997) Butterflies of Britain and Europe, 320 p. Harper Collins, London. [Hipparchia fagi: p. 189; pl. 58, 2仓, 1; Hipparchia alcyone: p. 190; pl. 58, 2今, 19]. alc bib A: 27

Tshikolovets V.V. (2011) Butterflies of Europe \& the Mediterranean area. Tshikolovets Publications, Pardubice, Czech Republic. [Hipparchia fagi (ScOPOLI, 1763): p. 420; Hipparchia hermione (LinnaEus, 1764) (= alcyone): p. 422; Hipparchia genava FRUHSTORFER, 1907 (recte: 1908): p. 423. The two individuals from Marseille being presented under Hipparchia genava represent in fact $H$. alcyone]. alc bib A: 28

VARIN G. (1962) Les sous-espèces françaises d'Hipparchia fagi Sc., alcyone Denis et Schiff. et neomiris God. Alexanor 2 (8): 313-324. alc bib A: 28

VERITY R. (1913) Revision of the Linnean Types of Palaearctic Rhopalocera. The Journal of the Linnean Society, Zoology, London 32 (215): 173-191. [Satyrus Hermione [1764] (=alcyone): p. 183-184]. alc bib A: 28

VERITY R. (1953) Le farfalle diurne d'Italia. 5. Divisione Papilionoidea, sezione Nymphalina, famiglia Satyridae. Marzocco, Firenze. [Hipparchia (Hipparchia) aelia Hoffm. = alcyone Schiff. (= genava): p. 322-326; pl. 73, fig. 12-37]. gen bib: 15

VolPe G. and JUTZELER D. (2001) Différenciation spécifique d'Hipparchia fagi (Scopoli, 1963) et d'Hipparchia alcyone (Denis \& Schiffermüller, 1776) de Campanie (Italie) et des régions limitrophes selon les caractères des ailes, des armatures génitales, de l'œuf et de la chenille (Lepidoptera: Nymphalidae, Satyrinae). Linneana Belgica 18 (1): 1-26. [In this publication, Hipparchia alcyone represents $H$. genava]. gen bib: 1619; fag bib: 11-13
David JUTZELER

Rainstrasse 4

CH-8307 Effretikon

E-mail: david.jutzeler@bluewin.ch
Received: 01.09.2021

Accepted: 01.11.2021

Published online: 31.12 .2021

Article number: ER25202103

doi: 10.24193/entomolrom.25.3 